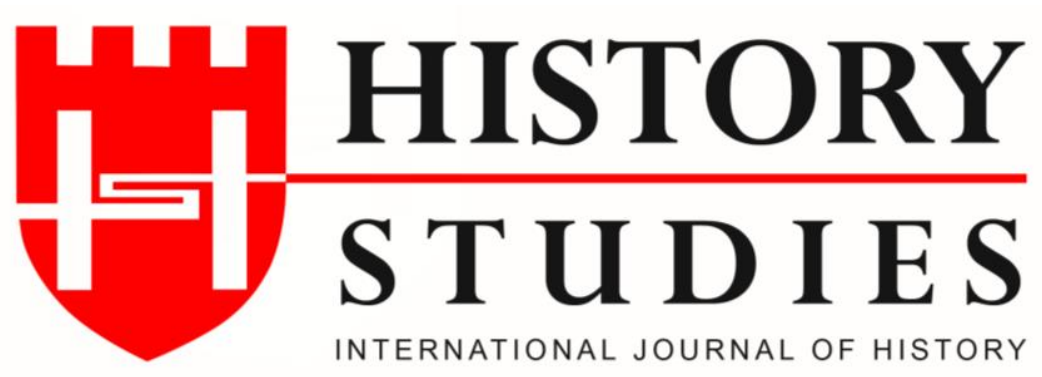

ISSN: 13094173 (Online) 1309 - 4688 (Print)

Volume 12 Issue 3, June 2020

DOI Number: 10.9737/hist.2020.861

Araştırma Makalesi

Makalenin Geliş Tarihi: 04.05.2020 Kabul Tarihi: 23.05.2020

Atıf Künyesi: Ferdi Uyanıker, “Cumhuriyet Devri Diplomat Naaşlarının Nakillerinde Savaş

Gemilerinin Kullanılması Örnekleri: Sovyet Rusya Büyükelçisi Vasıf Çınar ve Amerika Birleşik

Devletleri Büyükelçisi Minür Ertegün'ün Naaşlarının Türkiye'ye Getirilmesi”, History Studies, 12/3,

Haziran 2020, s. 927-960.

\title{
Cumhuriyet Devri Diplomat Naaşlarının Nakillerinde Savaş Gemilerinin Kullanılması Örnekleri: Sovyet Rusya Büyükelçisi Vasıf Çınar ve Amerika Birleşik Devletleri Büyükelçisi Minür Ertegün'ün Naaşlarının Türkiye'ye Getirilmesi
}

Two Cases of The Use of Warships in the Transfers of Deceased Diplomats of the

Volume 12 Turkish Republic: The Transfers of the Deceased Soviet ambassador, Vasif Çinar and United States Ambassador Munir Ertegun

\author{
Dr. Ferdi Uyanıker \\ ORCID No: 0000-0002-8587-1539 \\ Deniz Kuvvetleri Komutanlığ 1
}

Öz: Devletler, diplomasi işinin modern anlamda diplomatlar tarafindan yürütülmeye başlamasından sonra, kendi ülkelerinde vefat eden diplomatların naaşlarını ülkelerine savaş gemileriyle gönderme geleneğini benimsemiştir. Bu durum, hem karş1 devlete bir saygı göstergesi hem de kendi ülkesinin çıkarları için kullanılacak bir uygulama olmuştur. Türk tarihinde de bu uygulamanın örnekleri görülmüştür. Bu örneklerden ikisi Cumhuriyet tarihi içerisinde karşımıza çıkar. Hem de çok ilginç bir şekilde II.Dünya Savaşı öncesi ve sonrasında. İlk olay II.Dünya Savaşı öncesinde Sovyet Rusya'da hayatını kaybeden Sovyet Rusya Büyükelçisi Vasıf Çınar'ın naaşının bir Rus savaş gemisiyle Türkiye'ye nakledilme sürecidir. Diğer olay ise II.Dünya Savaşı sırasında Amerika'da vefat eden ve savaş sonrasında naaşı Türkiye'ye bir Amerikan savaş gemisiyle getirilen, Amerika Birleşik Devletleri Büyükelçisi Münir Ertegün'ün naaşının nakledilmesi olmuştur.

Anahtar Kelimeler: Vasıf Çınar, Münir Ertegün, Fuad Paşa, Missouri Zırhlısı, Chervonaya Ukraina Kruvazörü, Le Renard Gemisi

Abstract: When diplomacy started to be carried out by diplomats as in the modern sense, countries have adopted the tradition of sending the deceased diplomats to their countries by warships. This situation was both an indication of respect for the counter-state and an application to be used for the interests of its own country. Examples of this practice was seen in Turkish history as well. Two of these cases appeared in the history of the Turkish Republic; Surprisingly, one before the other after the Second World War. The first case was the transfer of the deceased Soviet ambassador, Vasıf Çınar, who died in Russia before the war by a Russian warship. The 
Cumhuriyet Devri Diplomat Naaşlarının Nakillerinde Savaş Gemilerinin Kullanılması Örnekleri...

second case was the transfer of the deceased United States Ambassador to Turkey, Munir Ertegun, who died during the Second World War by an American warship.

Keywords: Vasıf Çınar, Münir Ertegün, Fuad Pasha, Missouri Warship, Chervonaya Ukraina Cruiser, Le Renard Ship

\section{Giriş}

Kavramsal olarak "Diplomasi" ve "Diplomat" terimleri, devletlerin varlığıyla doğmuştur. Diplomasi; dış politika ve uluslararası politikanın, içeriğinden ziyade yürütülme şekliyle alakalıdır. Diplomasinin temel amaci; bir devletin herhangi bir mesele üzerindeki fikir ve düşüncelerini diğer devletlere aktarmasıdır. Diplomatlar ise bu işleri yürüten resmi görevlilerdir. ${ }^{1}$

Türk Devletlerindeki diplomatik faaliyetler, bu devletlerin doğuşu ile başlar. Ancak modern anlamda fiili elçiliklerin kurulması ve diplomatların görevlendirilmesi, Osmanlı İmparatorluğu döneminde gerçekleşir. Bu süreci Osmanlıda, 1793 tarihinden önceki dönem ve 1793 tarihinden sonraki dönem olmak üzere iki ayrı şekilde ele almak gerekir. Fiili olarak ilk elçiliklerin açıldığ 1793 tarihinden sonra, Batılı Devletlerle kurulan ilişkiler Osmanlı diplomasi geleneğini büyük değişimlere maruz bırakmış, bu süreç I. Dünya Savaşı, Milli Mücadele Dönemi ve Lozan Antlaşmasının imzalanmasıyla neticelenmiştir. ${ }^{2}$

Türk dış politikasını idare eden ve genel olarak "hariciyeci" veya "diplomat" olarak adlandırılan "meslek memurları"3 en değerli bürokratlar arasında sayılmıştır. Bu diplomatların görev başında hayatlarını kaybetmesi ise o devletlerin birbirleri ile olan ilişkileri açısından yeni pencereler açılarak, çeşitli firsatların doğmasında neden olabilmiştir. Üstelik vefat eden diplomatın naaşının bir savaş gemisi ile ülkesine gönderilmesi büyük önem arz eden tarihi bir olaydır. Yaşanmış böyle bir olaya, ilk olarak Osmanlı döneminde tesadüf edilmiş ve Türkiye Cumhuriyeti Devleti’nin kurulmasından sonra da bu uygulamanın örnekleri görülmüştür.

Görevli iken yurt dışında vefat eden ve naaşı ülkeye bir savaş gemisi ile gönderilen Osmanlı hariciyecisi, Keçecizade Mehmet Fuad Paşa olmuştur. Bu noktada altı çizilmesi gereken diğer bir hususta, Fuad Paşa'nın o dönemde Hariciye Nazırı olmasıdır.

Fuad Paşa, Tanzimat Dönemi’ne damga vuran, devrin en önemli siyasi aktörlerinden biridir. Beş kez hariciye nazırlığı iki kez de sadrazamlık yaparak, Osmanlı diplomasi tarihindeki önemli karakterler arasında yer almıştır. ${ }^{4}$ Ali Paşa ile birlikte Fransız sempatizanı olmakla tanınıp, çoğunlukla Fransa'ya yakınlaşılan dönemlerde iktidara gelseler de Fuad Paşa hiçbir zaman sorgusuz sualsiz Fransız yanlısı bir siyaset izlemedi. Reşid Paşa İngiltere, Ali Paşa Fransa yanlısı bir politika yürütürken, Fuad Paşa daima bu iki siyasetin ortasında bulunmayı tercih etti. ${ }^{5}$

Uzun yıllar çeşitli kademelerde devlet hizmetinde bulunan Fuad Paşa, doğuştan kalp hastasıydı. Hatta babası İzzet Molla 1829 yılının Ağustos ayında, oğulları Ahmed Nazım ve

\footnotetext{
${ }^{1}$ Tayyar Arı, Uluslararası İliş̧kiler ve Dış Politika, İstanbul 1997, s.297.

${ }^{2}$ Halil İnalcık, Kuruluş ve Imparatorluk Sürecinde Osmanlı, Timaş Yayınları, İstanbul 2011, s.189.

${ }^{3}$ Baskın Oran, Türk Dış Politikası (Kurtuluş Savaşından Bugüne, Olgular, Belgeler, Yorumlar), Cilt I 1919-1980, İletişim Yayınları, İstanbul 2002, s.55.

${ }^{4}$ Emine Atılgan Gümüşsoy, Keçecizâde Mehmed Fuad Paşa (1815-1869), (Gazi Üniversitesi Sosyal Bilimler Enstitüsü, Basılmamıs Doktora Tezi), Ankara 2006, s.7.

${ }^{5}$ Orhan Fuad Köprülü, "Fuad Paşa, Keçecizâde (1815-1869)", Türkiye Diyanet Vakfi İslâm Ansiklopedisi, C.XIII, Türkiye Diyanet Vakfı Yayınları, İstanbul 1996, s.204.
} 
Kâzım ise genç yaşlarında kalpten vefat etmişti. ${ }^{6}$ Sultan Abdülaziz ile meşhur Avrupa seyahatinden döndükten sonra, Fuad Paşa'nın aşırı yorgunluktan genetik kalp problemi büyüdü. Rahatsızlıklarının artması üzerine tedavi olmak ve 1868 kışını geçirmek için Fransa'nın Nice şehrine gitti. Bu sırada İstanbul'dan ayrılmadan önce 26 Eylül 1868 tarihinde, Hariciye Nazırlığı görevine vekalet etmek üzere Maarif Nazırı Saffet Paşa görevlendirildi. ${ }^{7}$

Nice'de bir yandan dinlenen bir yandan tedavisine devam edilen Fuad Paşa'nın durumu gün geçtikçe kötüleşti. Sonuç olarak 12 Şubat 1869 tarihinde hayatını kaybetti. ${ }^{8}$ Osmanlı Devleti'nin Hariciye Nazırının Fransa'daki ölümü, Fransız Devletini harekete geçirdi. Çünkü Kırım Savaşı ile başlayan Osmanlı Fransa yakınlaşmasında, rekabet halinde olduğu İngiltere'ye karşı, bu durumu lehlerine kullanma ihtimali doğmuştu. Fransız yetkililer hemen büyük bir cenaze töreni hazırlıklarına başladı. Bu sırada Fuad Paşa'nın cenaze töreni Floransa'da Osmanlı temsilcisi olarak görev yapan ve vefatından önce Fuad Paşa ile ilgilenen arkadaşı Rüstem Bey tarafından organize edildi ve naaşı, Paris elçilik yetkililerinden Hoca Tahsin Efendi'nin nezaretinde İslami usullere göre yıkanıp kefenlendi. Sonrasında 14 Şubat 1869 günü Paris’te bir Fransız askeri merasim kıtası ve şehrin ileri gelenlerinin iştirak ettiği cenaze töreni icra edildi. Fuad Paşa'nın naaşı, törene katılan büyük kalabalık ile birlikte Saint-François de Paule sokağ1 ve Panchettes güzergahı takip edilerek limana götürüldü. Tören günü hava çok rüzgarlı, deniz de oldukça dalgalıydı. Bu nedenle naaşı İstanbul'a taşıyacak Le Renard savaş gemisi liman dışında Villefranche'da açıkta demirliydi. Limandan yaklaşı $5 \mathrm{~km}$ uzaklıkta olan bu yere kadar cenaze korteji yürüyerek intikal etti. Buraya ulaşıldığında naaş, askeri törenle gemiye aktarıld1. ${ }^{9} \mathrm{Bu}$ esnada Villefranche sahilinde, törene katılmakta olan çok sayıda insan bulunmaktaydı. Ayrıca limandaki Fransız Bayrağı yarıya indirilerek, bir saygı göstergesi olarak işkampavyaların ${ }^{10}$ kürekleri selam şekli vaziyetine yani yukarıya doğru kaldırıldı. Aynı zamanda Le Renard savaş gemisinin grandi direğinde ${ }^{11}$ de oldukça büyük bir Osmanlı bayrağı bulunmaktaydı. Fuad Paşa'nın naaşı ise limandan işkampavya ile Le Renard savaş gemisine nakledildi. Bu sırada işkampavyada sadece bir dümenci ile naaşın yanında ayakta duran Fransa'daki Türk elçiliği imamı Hoca Tahsin Efendi yer almaktaydı. İşkampavya yedeklenerek ${ }^{12}$ Le Renard savaş gemisine götürüldü. ${ }^{13} \mathrm{Bu}$ vesileyle Fransa, icra ettiği bu kapsamlı cenaze merasimiyle, Osmanlıya verdiği önemi gösterme firsatı bulmuş oldu.

Fransa, Fuad Paşa'nın naaşının İstanbul'a götürülmesi için “Le Renard” isimli savaş gemisini görevlendirdi. Le Renard 3 direkli, yelken ve buhar gücüyle hareket edebilen, 1866 tarihinde imal edilmiş, ahşap çelik karışımı malzemeden yapılmış bir savaş gemisiydi. Gemi

\footnotetext{
${ }^{6}$ Y1lmaz Öztuna, Keçecizade Fuat Paşa, Kültür ve Turizm Bakanlığı Yayınları, İstanbul 1988, s.1.

${ }^{7}$ Öztuna, age, s.60; Gümüşsoy, agt, s.116; Köprülü, age, s.204.

${ }^{8}$ Köprülü, age, s.204.

${ }^{9}$ Bu sahne IIIustration'da Bonnefoy tarafindan çizilen krokide ve P. Blanchard tarafından yapılan bir gravür de tasvir edilmektedir. Bkz., Xavier Eyma,"Les Obseques de Fuad-Pacha”, L'Illustration-Journal Universel, LIII, S.1357, 27 Subat 1869 , s.Kapak ve 130.

${ }^{10}$ İşkampavya (Scampavia - Launch - Pinnage): Yaklaşık olarak 12 metre boyunda; kutrani kaplamalı, personel ve malzeme taşımasında kullanılan deniz taşıt aracı. Eski gemilerde yelken ve kürekle yürütülen bu tekneler; Bugün motorlu olarak kullanılmaktadır. Bkz., Burhanettin Seri, Denizcilik Ansiklopedisi, Deniz Basımevi, İstanbul 2009, s.267.

${ }^{11}$ Grandi Direği; Gemilerde pruva direğinden sonra geminin kıçına doğru olan ilk direktir. Bkz., Seri, age, s.158.

${ }^{12}$ Yedekleme (Towing - Towage -Hauling): Denizde herhangi bir nedenle, manevra yeteneğinden yoksun kalan gemilerin, diğer bir gemi tarafından çekilmek ya da bordaya alınmak suretiyle emniyetle en yakın limana ulaştırılması işlemine "yedekleme" denir. Denizde her gemi diğerini yedekleyebildiği gibi, bu işler için özel olarak inşa edilmiş makineleri güçlü manevra yeteneği yüksek römorkörler de kullanılır. Her geminin emniyeti açısından, açık denizde yedeğe girecek ya da yedeğe alacak donanımlara sahip olması gereklidir. Bkz., Seri, age, s.511.

${ }^{13}$ Semavi Eyice, "Tarihi Mezarlardan Notlar IV-Keçecizade Fuad Paşa'nın Mezarı”, İstanbul Üniversitesi Edebiyat Fakültesi Tarih Enstitüsü Dergisi, Edebiyat Fakültesi Matbaası, Ağustos 1973-1974, s.306.
} 
Cumhuriyet Devri Diplomat Naaşlarının Nakillerinde Savaş Gemilerinin Kullanılması Örnekleri...

68,74 metre boyunda, 8,4 metre eninde, 14 deniz mili sürate sahipti ve değişik ebatlarda 16 adet topu bulunmaktaydı. ${ }^{14}$ Fransızlar Fuad Paşa'nın vefat etmesinden sonra bu olaya verdikleri önemi göstermek üzere, Fuad Paşa'nın naaşını taşıması için özellikle böyle modern teknolojiye sahip, yeni bir savaş gemisi seçmişti.

Naaşı taşıyan Le Renard savaş gemisi, 15 Şubat 1869 tarihinde Çanakkale Boğazından geçişi esnasında, "Prince Bonaparte" isimli bir Fransız posta gemisine çarptı, çarpışma sonrasında Prince Bonaparte posta gemisi battı ve 13 denizci boğuldu. ${ }^{15}$ Ardından yoluna devam eden Le Renard savaş gemisi, 16 Şubat 1869 tarihinde İstanbul'a ulaştı ve Tophane önüne demirledi. Le Renard savaş gemisini Bahriye Nazırı Mahmud Nedim Paşa, Ticaret Nazırı Kabûli Paşa ve Kâmil Bey ile Saip Efendinin de aralarında bulunduğu kalabalık bir grup karşıladı. Karşılama sonrasında cenaze merasimine geçildi ve cenaze namazı 200 bine yakın kişinin katılımıyla Yenicami'de kılındı. Cenaze namazının kılınmasından sonra Fuad Paşa'nın naaşı, Fatih ilçesinin Sultanahmet semtinde bulunan Peykhane caddesinde yaptırdığı caminin yanına defnedildi. Kabrinin üstüne ise ilerleyen yıllarda bir türbe yapıldı. ${ }^{16}$

Osmanlı döneminde Fuad Paşa'nın vefatı sonrası görülen, diplomat naaşlarının savaş gemisiyle ülkesine gönderilmesi yöntemi, Türk tarihinde bir ilk olarak tarih sayfalarındaki yerini ald1. Hatta bir Osmanlı diplomatı için uygulanan bu yöntem, daha sonraki yıllarda Türkiye Cumhuriyeti'nin kuruluşundan sonra da benzer mantık çerçevesinde tekrar etti. Aradan geçen y1llara rağmen Cumhuriyet diplomasisi, Osmanlı diplomasisinin doğal uzantıss ${ }^{17}$ olma özelliğini korumuş, Dünya diplomasisinin mantığı da değişmemişti. Bu mantık dairesi içerisinde, Cumhuriyet döneminde aynı yöntem ile naaşları Türkiye'ye gönderilen diplomatlar, Vasıf Çınar ve Münir Ertegün oldu. Yani Sovyet Rusya'da büyükelçi iken vefat eden Vasıf Çınar ve Amerika Birleşik Devletlerinde büyükelçi iken vefat eden Münir Ertegün'ün naaşları, yine o ülkelere ait savaş gemileriyle Türkiye'ye gönderildi. Bu uygulamalarda da amaçlanan şey Fransa'nınkinden farklı değildi. Nasıl ki 1869 tarihinde Fransa, Osmanlı Devleti ile olan ilişkilerini güçlendirmek ve daha fazla yakınlaşmak için bu yöntemi uyguladı ise 1935 yılında Rusya ve 1946 yılında da Amerika'nın amacı aynıydı.

\section{Sovyet Rusya Büyükelçisi Vasıf Çınar Naaşının Türkiye'ye Getirilmesi}

\subsection{Vasıf Çınar'ın Hayatı ve Sovyet Rusya Büyükelçiliği Döneminde Türkiye-Sovyet Rusya İlişkileri}

Vasıf Çınar 1892 tarihinde Girit’te doğdu. ${ }^{18}$ Şimdiki adı Atatürk Lisesi olan İzmir İdadisi’nil bitirdi. Adından İstanbul Hukuk Mektebi’ne başladı fakat üçüncü sınıfta bıraktı. İzmir'e

\footnotetext{
${ }^{14}$ Le Renard savaş gemisi 3 Haziran 1885 tarihinde Aden'e gitmek üzere şimdiki Cibuti bağlısı Obock'tan yola çıktı. Ancak denizde şiddetli bir fırtına patladı ve Le Renard battı. Yapılan aramalarda gemiye ait hiçbir parça bulunamadı. https://www.wrecksite.eu/wreck.aspx?286303 (E.T. 08.04.2020); https://fr.wikipedia.org/wiki/Le_Renard_(aviso) (E.T. 08.04.2020)

${ }^{15}$ Bu olayla ilgili olarak Ahmet Lütfü Efendi yazdığı "Tarih" adlı eserinde Le Renard savaş gemisinin Sardunya Adası önlerinde başka bir Fransız gemisiyle çarpıştığını ve Le Renard'da hasar meydana geldiğini söyleyerek, naaşın başka bir gemiye nakledildiğini ve İstanbul'a ulaştırıldığını yazar. Bkz., Ahmet Lütfü, Vak'a-Nüvis Ahmed Lütfi Efendi Tarihi, Hzl. Münir Aktepe, C.XII, Türk Tarih Kurumu Yayınları, Ankara 1989, s.40.

${ }^{16}$ Eyice, agm, s.306-309; İbnülemin Mahmud Kemal İnal, Son Sadrazamlar I-V, Milli Eğitim Bakanlı̆̆ Devlet Kitapları Basımevi, İstanbul 1969, s.177; Eyma, agm, s.130; Fuad Paşa Camii ve Türbesi, Sultanahmet semtinde Binbirdirek mahallesinde, Klodfarer caddesiyle Peykhane sokağının kesiştiği köşede bulunmaktadır. Fuad Paşa tarafından Uzun Şücâ' Mescidi'nin yerinde yaptırılmıştır. Bu mescidin Fazlı Paşa Sarayı Mescidi ile aynı yapı olduğu tahmin edilmektedir. Ayrıntılı bilgi için bkz., Köprülü, age, s.204.

${ }^{17}$ Oran, age, s.23.

${ }^{18}$ Vasıf Çınar'ın doğum tarihi ile ilgili olarak farklı tarihler belirtilmektedir. Gerçek doğum tarihinin 1892 olduğu ile ilgili doğum belgesinin bulunduğu, Türk Eğitim Derneği’nin 27 Ekim 1999 tarihinde düzenlediği "Vasıf Çınar'ın Yaşamı ve Hizmetlerine Toplu Bir Bakış" konulu VII. Anma Toplantısında Prof.Dr. Zeki Arıkan tarafindan beyan
} 
gelerek arkadaşı Mustafa Necati ile Şark İdadisi isminde bir okul açtı. Bunun yanında İzmir'de ilk spor okulunu kuranlar arasında yer aldı. Yine Mustafa Necati ile birlikte 1912 tarihinde İstanbul'da Türk Ocağı'nı kurdu. Türk Ocağı'nın bir şubesini İzmir'de açmak için büyük bir mücadele verdi ve ciddi engellemelere karşın Kemeraltı'ndaki ocağın açılışı gerçekleşti. Ancak Vasıf Çınar, ocak açıldıktan sonra İzmir Valiliğine İzzet Bey'in getirilmesiyle daha zor durumda kaldı. İzmir'in işgali sonrasında ise ocaktaki tüm belgelere ve kitaplara el konularak, ocak ateşe verildi. İzmir'in işgali sonrası Reddi İlhak Cemiyetinin kurucuları arasında yer aldı. Vasıf Çınar Milli Mücadele yıllarında Ege çevresinde Yunan işgallerine karşı büyük bir mücadele örneği sergiledi. Bu süreçte İstiklal Mahkemesinde savcılık görevi yaptı. İlaveten Balıkesir'de çıkarılan “İzmir'e Doğru” gazetesinde Milli Mücadeleyi destekleyen yazılar kaleme aldı. İzmir' in kurtuluşundan sonra da İzmir Milli Eğitim Müdürlüğü’ne atandı. Aynı zamanda "Muallimler Birliğì"ni kurarak, İzmir Türk Ocağı'nı yeniden açtı ve "Türk Sesi”" adlı bir gazete yayınlamaya başladı. Bu çalışmalar sırasında yanında, Hasan Ali Yücel ve Mustafa Necati ile kardeşi Mahmut Esat Çınar bulunuyordu. ${ }^{19}$

11 Ağustos 1923 ve 5 Temmuz 1934 tarihlerinde yapılan seçimlerde Saruhan milletvekili seçildi. 6 Mart 1924 tarihinde Maarif Vekili (Milli Eğitim Bakanı) oldu. Milletvekilliği ve Bakanlığı sırasında Tevhid-i Tedrisat Yasasının hazırlanması ve üniversitenin modernize edilmesi konularında gayret gösterdi. Maarif, mübadele, imar ve iskan komisyonlarında yer aldı ve en aktif milletvekillerinden biri olarak göze çarptı. Ancak Maarif Vekilliği, muhafazakar çevrelerden gelen eleştiriler nedeniyle, 21 Kasım 1924 tarihinde istifa etmesiyle sona erdi. 16 Haziran 1925 tarihinde Prag Büyükelçiliğine getirildi. Bu görevine 2 y1l devam etti ve 11 Aralık 1927 tarihinde Budapeşte Büyükelçiliğine atandı. Bu görevi de 1 yıl sürdü ve 3 Kasım 1928 tarihinde Moskova Büyükelçiliği görevine getirildi. Bu sırada Maarif Vekili Mustafa Necati ölünce, boşalan İzmir milletvekilliğine seçildi. Ardından yeniden 26 Şubat 1929 tarihinde Maarif Vekili oldu. 1929 yılının Mayıs ayında Roma Büyükelçisi yapıldı. Roma Büyükelçiliği görevinden 16 Temmuz 1934 tarihinde ayrılarak 10 Eylül 1934 tarihinde yeniden Moskova Büyükelçiliğine getirildi. ${ }^{20}$

Böylelikle Vasıf Çınar, 1928-1929 yıllarında yürüttüğü Moskova Büyükelçiliği görevine, 1934 tarihinde yeniden getirilmiş oldu. Vasıf Çınar'ın, kesintili de olsa Moskova Büyükelçiliği görevini devam ettirdiği 1928-1935 tarihleri arasındaki Türkiye Sovyet Rusya ilişkileri için; ciddi sorunlarla karşılaşılmayan hatta yüzyıllar süren düşmanlık döneminden, dostluk ilişkilerinin güçlendiği aşamaya geçiş dönemi şeklinde bir tanımlama yapılabilir. Rusya'da yaşanan Bolşevik İhtilali sonrası başlayan olumlu tablo, Batılı güçlere karşı Mustafa Kemal Atatürk ve Lenin'in ortaya koyduğu irade sonucunda, birlikteliğe dönüştü. Bu dönemin temelleri ise Mustafa Kemal Atatürk'ün Lenin'e mektubu ${ }^{21}, 1920$ tarihinde Bekir Sami Bey'in Moskova çalışmaları ${ }^{22}$, Yusuf Kemal Bey’in 16 Mart 1921 tarihinde imzalanan "Moskova

edilmiştir. Bkz., Zeki Arıkan, "Vasıf Çınar'ın Yaşamı ve Hizmetlerine Toplu Bir Bakış", Vasıf Çınar Yaşamı ve Hizmetleri Anma Toplantısl, Türk Eğitim Derneği VII. Anma Toplantısl, (27 Ekim 1999 Ankara), Türk Eğitim Derneği Yayınları, Ankara 1999, s.51.

${ }^{19}$ Kavcar, age, s.7-17; Tülay Alim Baran, Vasıf Çınar ve İzmir'e Doğru Gazetesi Yazıları, İstanbul 2001, s. 11-13.

${ }^{20}$ Necdet Sakaoğlu, "Vasıf Çınar ve Tevhid-i Tedrisat Kanunu", Vasıf Çınar Yaşamı ve Hizmetleri Anma Toplantısı, Türk Eğitim Derneği VII. Anma Toplantısı, (27 Ekim 1999 Ankara), s.17-32; Ragıp Uğural, "Vasıf Çınar ve İzmir'e Doğru”, Vasıf Çınar Yaşamı ve Hizmetleri Anma Toplantısı, Türk Eğitim Derneği VII. Anma Toplantısı, (27 Ekim 1999 Ankara), s.34-41; Orhun Köstem, "Ailesinden Biri Gözüyle Vasıf Çınar”, Vasıf Çınar Yaşamı ve Hizmetleri Anma Toplantısı, Türk Eğitim Derneği VII. Anma Toplantısı, (27 Ekim 1999 Ankara), s.41-49.

${ }^{21}$ Fahir Armaoğlu, "1920 Yilında Millî Mücadele ve Sovyet Rusya”, VII. Türk Tarih Kongresi Bildirileri, Türk Tarih Kurumu Yayınlar1, Cilt II, Ankara 1973, s.893, 895.

${ }^{22}$ Fahir Armaoğlu, 20. Yüzyll Siyasi Tarihi 1914-1995, Cilt I-II, Alkım Yayınevi, İstanbul 2005, s.312. 
Dostluk ve Kardeşlik Antlaşması" ile sonuçlanan faaliyetleri ${ }^{23}, 17$ Aralı 1925 tarihinde Paris'te imzalanan "Türk-Sovyet Dostluk ve Saldırmazlık Paktı" ${ }^{24}$ ve 11 Mart 1927 tarihinde Ankara'da imzalanan "Ticaret ve Seyrisefain Andlaşması" gerekirse iki devlet, köklü bir tarihe sahip olsa da yeni isimler altında kurulan genç devletler olmaları ve coğrafi kader ortaklıkları nedenleriyle birbirlerine yakınlaştı. İlaveten devletlerarası alanda yeni devletler olmaları sebebiyle, aradıkları ortaklıklarda görülen problemler ile yakın geçmişlerinden edindikleri tecrübelerle, Avrupalı devletlere duyulan itimatsızlık da genç Türk ve Sovyet Devletlerini birbirlerine çekti.

Güçlü bir şekilde atılan bu temel sonrası 1928-1935 tarihleri arasındaki Türkiye Sovyet Rusya ilişkileri; "1929 Litvinov Protokolü”, Dışişleri Bakanı Tevfik Rüştü'nün 1930 yılının Eylül ve Ekim aylarında gerçekleştirdiği Moskova ziyareti, 17 Mart 1931 tarihinde Ankara'da imzalanan "Karadeniz ve Ona Bitişik Denizlerde Deniz Kuvvetlerinin Sınırlandırılmasına İlişkin Protokol" ve Başvekil İsmet Paşa'nın 25 Nisan-10 Mayıs 1932 tarihleri arasındaki Rusya ziyareti çerçevesinde şekillendi.

Bu süreçte Türkiye Sovyet Rusya ilişkilerinde dikkat çeken ilk olay, 9 Şubat 1929 tarihinde Moskova'da imzalanan "Litvinov Protokolü" oldu. Protokol; Romanya, Polonya, Estonya ve Letonya ile imzalanmıştı. 1928 tarihinde imzalanan Kellogg Paktı'na Türkiye ile Sovyetler Birliği katılınca Ruslar, Kellogg Paktı'nın daha geniş bir alanda uygulanabilmesi maksadıyla, Litvinov Protokolü'nün doğmasına zemin hazırladı. Türkiye Litvinov Protokolü’ne 1 Nisan 1929 tarihinde dahil olarak, Rusya ile ilişkilerini güçlendirmiş oldu. ${ }^{26}$

Türk-Rus ilişkilerinde önemli köşe taşlarından biri de Dışişleri Bakanı Tevfik Rüştü Aras'ın 1930 yılı Eylül ayında yaptığ 1 Rusya ziyareti oldu. ${ }^{27}$ Ziyaret, 3 Ekim 1930 tarihindeki ortak bildiri ile tamamlandı. Devamında Ankara'da, Rusya Büyükelçisi Surits ve Dışişleri Bakanı Aras arasında 17 Mart 1931 tarihinde "Karadeniz ve Ona Bitişik Denizlerde Deniz Kuvvetlerinin Sınırlandırılmasına İlişkin Protokol" imzalandı. Protokol "Bağıtlı Yüksek Taraflardan her biri, öteki Bă̆ıtl Tarafa 6 ay önce bildirmeden, Karadeniz'de ya da ona bitişik Denizlerdeki savaş donanmaların güçlendirecek herhangi bir savaş gemisini tezgâha koymayacak ya da böyle bir gemiyi yabancı gemi tezgâhlarına ısmarlamayacak ya da söz konusu denizlerde bulunan kendi savaş donanmasının şimdiki gücünü arttırmak sonucunu verebilecek herhangi bir başka önlem almayacaktır." şeklindeydi. Bu protokol 22 Temmuz 1931 tarihinde yürürlüğe girdi. 17 Mart 1931 tarihinde ayrıca, 1925 tarihli antlaşmayı 5 yıl daha uzatan protokol de imzalandı. Böylece Türk-Rus ilişkileri daha da güçlendirilmiş oldu. ${ }^{28}$

Bu süreçte iki ülke arasındaki ilişkilerin zirve noktası ise Başvekil İsmet İnönü'nün 25 Nisan-10 Mayıs 1932 tarihleri arasında gerçekleştirdiği Rusya ziyareti oldu. Bu ziyaret, 1931 yılı Kasım ayında Türkiye'yi ziyaret eden Sovyet Rusya Dış İşleri Bakanı Litvinov'un daveti ile gerçekleşti. ${ }^{29}$ Ziyaretten beklenenler arasında; Türkiye'nin Batılı Devletlerle olan ilişkilerinden Rusya'nın duyduğu kuşkuları gidermek, Rus Devlet yöneticileri ile dostluk sağlamak, Milletler Cemiyetine girilmesi hakkında Rusya'nın onayını almak, Balkan Paktı

\footnotetext{
${ }^{23}$ Oran, age, s. 145 .

${ }^{24}$ Şerafettin Turan, Mustafa Kemal Atatürk, Kendine Özgü Bir Yaşam ve Kişilik, Bilgi Yayınevi, Ankara 2008, s.640.

${ }^{25}$ Rifat Uçarol, Siyasi Tarih 1789-1994, Filiz Kitabevi, İstanbul 1995, s.565.

${ }^{26}$ Age, s.565.

${ }^{27}$ Ziyaret hakkında Mustafa Kemal Atatürk, 1 Teşrinisani 1930 tarihli TBMM açış konuşmasında bilgi vermiştir. Konuşma için bkz., Atatürk'ün Türkiye Büyük Millet Meclisi Açış Konuşmaları, TBMM Basımevi, Ankara1987, s.187-193.

${ }^{28}$ Oran, age, s.319.

${ }^{29}$ Mete Tunçay, Türkiye'de Sol Akımlar (1925-1936), Cilt II, BDS Yayınları, İstanbul 1992, s.95.
} 
girişimi hakkında Rusya'yı bilgilendirmek, sanayileşebilmek adına Sovyet Rusya'nın desteğini almak ve yaklaşan savaş nedeniyle Rusya'nın Türkiye hakkındaki düşünce ve politikasını öğrenmeye çalışmak gelmekteydi. Çok olumlu bir atmosferde gerçekleşen ziyaret neticesinde iki ülke arasındaki yakınlaşma bir nebze daha artmış oldu. ${ }^{30}$

\subsection{Vasıf Çınar'ın Vefat Etmesi ve Naaşının Türkiye'ye Nakledilme Süreci}

Vasıf Çınar 30 Mayıs 1935 tarihinde akşam saatlerinde evinde rahatsızlandı. Karın bölgesinde şiddetli sancılar duymaya başlayan Büyükelçi, bir taraftan da kusuyordu. Sabah çağırılan Prof. Frongolot yaptığı muayenede; bağırsak düğümlenmesi ile peritonda ${ }^{31}$ bir irritasyon $^{32}$ olduğu teşhisini koydu. Prof. Hertzen ve Burdenko da konsültasyonda bulunarak aynı teşhisi onayladı. Bağırsak sorununu çözmek için yapılan gayretler boşa çıkınca ve 1 Haziran sabahı sancılar azalmakla beraber hasta ağırlaştığı için Kremlin hastanesine kaldırıldı. $\mathrm{O}$ gün ve gece akademisyen Krol, röntgen uzmanı Prof. Frenkel, profesörler Frongolot, Hertzen, Burdenko, Luiborg, Vinogradof ile doktorlar Levin ve Sokolof konsültasyonlar yaptı. Konsültasyon neticesinde; kalbin aniden zayıfladığı, tansiyonun düştüğü ve idrarda şeker bulunduğu belirlenerek, hastanın şişmanlığ 1 da dikkate alınarak konservatif bir tedavi programı belirlendi. Çünkü hasta ameliyat sırasında kaybedilebilirdi. Ancak 2 Haziran günü saat 03:30'da Büyükelçinin durumu ağırlaşınca ameliyata mecbur kalındı. Ameliyatta bağırsakların durumunun çok kötü olduğu görüldü. Ameliyatın tamamlanmasının ardından kalbin durumu kötüleşti. Saat 08:40'ta kalbinin durması ve solunum yetmezliğinden Büyükelçi Vasıf Çınar vefat etti. ${ }^{33}$

Vasıf Çınar'ın vefatının ardından Merkez Yürütme Komitesi Başkanı Kalenin Cumhurbaşkanı Atatürk'e, Halk Komiserleri Kurulu Başkanı Molotof Başbakan İsmet İnönü'ye, Dışişleri Bakanı M. Litvinov Dışişleri Bakanı Tevfik Rüştü Aras'a başsağlığı telgrafı gönderdi. Ayrıca Dışişleri Bakanı yardımcısı Krestinski de Türkiye'nin Rusya Maslahatgüzarı Nureddin Pınar'ı ziyaret ederek Sovyet hükümeti adına başsağlığı dileklerini iletti. ${ }^{34}$

Kremlin hastenesinde bulunan merhum Büyükelçi Vasıf Çınar'ın tabutu, Türk bayrağına sarılı olduğu halde 3 Haziran günü öğlen saatlerinde otomobille Bolşaya Nikitskaya 43/A numarada bulunan Büyükelçilik binasına nakledildi. ${ }^{35}$ Naaşının hastaneden ayrılması sırasında resmi tören yapılmamasına rağmen merasimde Dışişleri Bakanı M. Litvinov, Harbiye Komiseri Voroşilov, Harici Ticaret Komiseri Rozengoltz, Dışişleri Bakanlığının çeşitli üst düzey

\footnotetext{
${ }^{30}$ Ersin Müezzinoğlu, "İsmet Paşa'nın 1932 Sovyet Rusya Ziyareti”, Afyon Kocatepe Üniversitesi Sosyal Bilimler Dergisi, Cilt 20, Sayı 2, Eylül 2018, s.252.

${ }^{31}$ Periton (peritoneum): Karın zarı, karın ve pelvis boşluğunu kaplayan (paryetal / parietal periton) ve bunların içindeki organları da saran (visseral / visceral periton) zar. Başlica iki tabakadan oluşur. Mezotel (tek katlı skuamöz/squamous epitel) ve bağ dokusu. Bağ dokusunun içinde kan ve lenfatik damarlar ve sinirler bulunur. Peritonla kaplı bu karın ve pelvis boşluğuna "periton boşluğu (peritoneal cavity)" denir. Bkz., http://www.turkcerrahi.com/tip-sozlugu/periton (E.T. 11.09.2019)

32 İrritasyon: [İng. Irritation] Tahriș; deri veya mukozada tahriş nedeniyle oluşan durum, inflamasyon ön durumu. İrritan madde ile oluşur. Bkz., http://www.turkcerrahi.com/tip-sozlugu/periton (E.T. 11.09.2019)

${ }_{33}$ Cumhuriyet, 03 Haziran 1935, s.1, 6; Akşam, 03 Haziran 1935, s.1, 2; Ulus, 03 Haziran 1935, s.1, 2, 3; Cumhuriyet, 04 Haziran 1935, s.1, 4; Akşam, 04 Haziran 1935, s.1, 4; Kurun, 04 Haziran 1935, s.1, 9; Ulus, 04 Haziran 1935, s.1, 6.

${ }^{34}$ Cumhuriyet, 03 Haziran 1935, s.6; Akşam, 03 Haziran 1935, s.2; Ulus, 03 Haziran 1935, s.1.

${ }^{35}$ Vasıf Çınar'ın tabutunun getirildiği Büyükelçilik binası, 1923 yılında Bolşevik Hükümeti tarafından bir yabancı misyona tahsis edilmek üzere Dışişleri Komiserliğine devredilmiştir. Bilahare Türk Hükümeti binayı Büyükelçilik olarak kiralamış ve Şubat 1924-Mart 1973 tarihleri arasında binayı hem kançılarya hem ikametgah olarak kullanmıştır. Bina Türkiye Cumhuriyeti Hükümeti tarafından 16 Temmuz 1971 tarihinde satın alınmış olup, anılan tarihten bu yana sadece Büyükelçilik ikametgahı olarak kullanılmaktadır. Bkz., http://moskova.be.mfa.gov.tr/Mission/About (E.T. 11.09.2019)
} 
görevlileri ile İtalya'nın Moskova Büyükelçisi M. Attoliko, İran Büyükelçisi Said ve Afganistan Büyükelçisi Abdülhüseyin Han Aziz ve bütün kordiplomatik hazır bulundu. Büyükelçilik binasında aynı gün saat 18:00'da tören düzenlendi. Törende Sovyet Akademi Tiyatrosu orkestrası matem marşları çaldı. Törene İtalyan Büyükelçisi M. Attoliko, Amerikan Büyükelçisi M. Bullitt, Afganistan Büyükelçisi Abdülhüseyin Han Aziz, Çin Büyükelçisi Z. Yen, Romanya Ortaelçisi M. Ciuntu, Fransa maslahatgüzarı Payard, İran maslahatgüzarı Saed, Yunanistan maslahatgüzarı Stefano ve Uruguay maslahatgüzarı Nosa iştirak etti. Öte yandan aynı törende Dışişleri Bakanlığ Doğu Şubesi Şefi Kukerman ve Protokol Şefi Barkov, Merkez Yürütme Komitesi Başkanlığı Sekreterlik Şefi Miagki hazır bulundu. Yine törende bulunanlardan Genelkurmay Başkanı Mejininov da; Merkez Yürütme Komitesi, Dışişleri Bakanlığı ve Savunma Bakanlığı adına başsağlığı dileklerini iletti. ${ }^{36}$

Elçilik binasındaki cenaze merasimi 4 Haziran günü saat 18:00'da icra edildi. Merasimin tamamlanmasının ardından Büyükelçi Vasıf Çınar'ın naaşı saat 19:45'te Kurski tren istasyonuna getirildi. Elçilikten tren istasyonuna giden 4 kilometrelik yol yaya olarak yüründü ve diğer tüm ulaşım vasıtalarının seferleri durduruldu. Bu sırada sokak ve caddelerdeki halk cenaze kortejini selamladı. Tabut büyük bir Türk bayrağına sarılı olduğu halde top arabasında konulmuştu. Top arabasının etrafında bir topçu müfrezesi bulunuyordu. Kortejin başında askeri kıta ve askeri bando yer alıyor ve ondan sonra merhum Vasıf Çınar'ın madalyalarını ipek bir yastık üzerinde taşıyan tören üniformasını giymiş Askeri Ataşe Enver yürüyordu. Daha arkada da Sümerbank tarafından Rusya'ya eğitime gönderilmiş Türk öğrenciler geliyordu. Kortejde ayrıca Türkiye'nin Rusya maslahatgüzarı Nurettin Pınar ve tüm elçilik görevlileri, Sovyet hükümeti adına başta Dışişleri Bakanı M. Litvinov olmak üzere çeşitli düzeyde görevliler, tüm yabancı elçilik yetkilileri ile kara, deniz ve hava askeri ataşeleri ve bölgede yaşayan Türkler bulunmaktaydı. Kurski tren istasyonuna ulaşıldığında tabut Türk elçilik görevlilerince taşınarak özel olarak hazırlanmış vagona konuldu. Vagon, saat 20:15'te hareket eden eksprese bağlanarak Sivastopol'e hareket etti. Merhum Büyükelçi Vasıf Çınar'ın naaşına Sivastopol'e kadar maslahatgüzar Nurettin Pınar refakat edecekti. Aynı trende, naaşı İstanbul'a kadar götürecek Viskonsolos Fuat Bey ve Sovyet Dışişleri Komiserliği siyasal kısım memurlarından Miller de bulunmaktaydi. ${ }^{37}$

Kurski tren istasyonundan yola çıkan naaş 6 Haziran günü Sivastopol tren istasyonuna ulaştı. Tren, Karadeniz filosu komutanı Kojanof ile Merkezi Yürütüme Komitesi Başkan Yardımcısı Bay Çaryi, Kırım Halk Komiserleri Başkan Yardımcısı Bay Milukof, Sivastopol Belediye Başkanı Bay Harçenko, Sivastopol Belediye temsilcileri, deniz askerleri tarafından selamland1. Kojanof ile Harçenko Sovyetler Birliği ile iyi ilişkileri olan Büyükelçinin vakitsiz ölümü dolayısıyla Rus Donanması, Kırım hükümeti ve Sivastopol Belediyesi adına başsağlığı dileklerinin Türk hükümetine bildirmesini maslahatgüzar Nurettin Pınar'dan rica etti.

Tren istasyonu önünde tabut yeşil dal ve çiçeklerle örtülü bir top arabası üzerine konuldu ve top arabasının en önünde maslahatgüzar Nurettin Pınar yer aldı. Nurettin Pınar bir yastık üzerinde Vasıf Çınar'a ait İstiklâl Madalyasını taşıdı. Kortejde deniz okulu öğrencileri de yer ald1. Sokaklar mateme uygun şekilde düzenlenmişti. Sokaklarda bulunan binlerce işçi iki ulus arasındaki dostluğun gösterilmesi bakımından önemliydi. Tabut Chervonaya Ukraina kruvazörüne bir vapur ile taşındı. Vapura Karadeniz filosu komutanı Kojanof ile Sivastopol Belediye Başkanı Bay Harçenko, kara, deniz filosu ve Sivastopol Belediyesi adına çelenkler

\footnotetext{
${ }^{36}$ Cumhuriyet, 03 Haziran 1935, s.4.

${ }^{37}$ Cumhuriyet, 05 Haziran 1935, s.1, 7, 9; Akşam, 05 Haziran 1935, s.2; Kurun, 05 Haziran 1935, s.2; Ulus, 04 Haziran 1935, s.1, 3; Cumhuriyet, 06 Haziran 1935, s.5; Akşam, 06 Haziran 1935, s.5; Ulus, 04 Haziran 1935, s.2.
} 
konuldu. Chervonaya Ukraina kruvazörü, bayrağını matem işareti olarak yarıya indirdi ve tam öğle vakti bir uçak fillosunun beraberinde kıyıdan uzaklaşt.. ${ }^{38}$

\subsection{Rus Kruvazörü Chervonaya Ukraina'nın Açı Denizde Kocatepe Muhribi Tarafindan Karșılanması ve İstanbul'da İcra Edilen Cenaze Merasimi}

Sovyet hükümeti Türkiye ile son dönemde yaşanan olumlu ilişkiler çerçevesinde Vasıf Çınar'ın naaşının İstanbul'a bir Rus kruvazörüyle gönderilmesini düşündü. Bu uygulama ile Türkiye'ye verilen değer gösterilmiş olacaktı. Çünkü yaklaşan II.Dünya Savaş1 öncesinde Türkiye, Rusya için çok önemli bir müttefik olabilirdi. Rusya bu hareketi ile başta Amerika olmak üzere Dünyaya da mesaj vermek gayesindeydi.

Ruslar, Vasıf Çınar'ın naaşının İstanbul'a götürülmesi görevini Amiral Nakhimov sınıfından Chervonaya Ukraina kruvazörüne verdi. ${ }^{39}$ Chervonaya Ukraina kruvazörü 6 Haziran günü öğlen saatlerinde Sivastopol'den hareket etti. Gemiyi açık denizde karşılamak ve yanaşacağı Haydarpaşa limanına kadar eşlik etmek üzere Kocatepe muhribi ${ }^{40}$ görevlendirildi. Kocatepe muhribi bu süreçte, İstanbul ziyaretini gerçekleştiren Fransız okul gemisi Jeanne D'arc ${ }^{41}$ kruvazörü $^{42}$ ile meşguldü. ${ }^{43} 30$ Mayıs günü saat 16:00'da Haydarpaşa limanına demirleyen

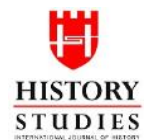

935

Volume 12

Issue 3

June

2020

${ }^{38}$ Ulus, 08 Haziran 1935, s.5.

${ }^{39}$ Bu kruvazör 1915 yılında Nikolaiev tersanesinde imal edilmişti. Geminin deplasmanı boş iken 6600 ton, tam yüklü iken 6634 ton, taşıdığı personel 624 kişi, uzunluğu 166,7 metre, yüksekliği 15,7 metre, draftı (geminin su çekimi) 6,20 metreydi. Gemide bulunan silahlar ise şunlard1; 15 adet 5,1 inçlik top, 8 adet 4 inçlik top, 4 adet makineli tüfek, 100 adet mayın ve 2 adet vinçle denize indirilen deniz uçağı. Ayrıntılı bilgi için bkz., T.Fred Jane's, All The World Fighting Ships 1940, Francis E., McMurtie, London, England 1940, s.399.

40 Kocatepe muhribi, 1929 y1lında İtalya ile dostane ilişkilerin olduğu bir süreçte İtalyanlara sipariş edilen gemilerdendir. İlk etapta 2 muhrip sipariş edilmiş, daha sonra İtalyanların 2 muhrip daha verebiliriz teklifi üzerine sayı 4'e yükseltilmiştir. Muhripler Cenova limanındaki Ansoldo tersanesinde imal edilmiştir. Kocatepe, Adatepe, Tinaztepe ve Zafertepe adı verilen muhriplerden Kocatepe muhribi ,Adatepe muhribiyle birlikte 18 Teşrinievvel 1931 tarihinde Türkiye'ye getirilmiştir. Ayrıntılı bilgi için bkz., Türk Deniz Kuvvetleri Tarihçesi 1923-1935, Lalahan Deniz Genel Arşiv Müdürlügü Yayını, Cilt Nu.,I., Ankara, s.I-55, 60, 61, 62, V-8, 9, 22, 24; Cumhuriyet, 12 Teşrinievvel 1931, s.2; Akşam, 12 Teşrinievvel 1931, s.4; Cumhuriyet, 16 Teşrinievvel 1931, s.1, 2; Hakimiyet-i Milliye, 16 Teşrinievvel 1931, s.4; Vakit, 16 Teşrinievvel 1931, s.1; Cumhuriyet, 17 Teşrinievvel 1931, s.2; Akşam, 17 Teşrinievvel 1931, s.1; Hakimiyet-i Milliye, 17 Teşrinievvel 1931, s.1; Cumhuriyet, 18 Teşrinievvel 1931, s.1; Akşam, 18 Teşrinievvel 1931, s.1; Hakimiyet-i Milliye, 18 Teşrinievvel 1931, s.1; Vakit, 18 Teşrinievvel 1931, s.1; Cumhuriyet, 19 Teşrinievvel 1931, s.1; Hakimiyet-i Milliye, 19 Teşrinievvel 1931, s.4; Vakit, 19 Teşrinievvel 1931, s.6; Cumhuriyet, 20 Teşrinievvel 1931, s.1; Hakimiyet-i Milliye, 20 Teşrinievvel 1931, s.1; Vakit, 20 Teşrinievvel 1931, s.2, 4; Cumhuriyet, 23 Teşrinievvel 1931, s.5.

${ }^{41}$ Fransızların Deniz Harp Okulu öğrencilerini eğitmek için kullandıkları kruvazöre adını verdikleri Jeanne D'arc, oldukça karışık bir ortamda 1412 yılında Fransa'nın Domrémy adlı kasabasında dünyaya geldi. Jeanne, ailesi gibi inançlı ve sıradan bir köylü kızıydı. Jeanne D'arc, henüz on üç yaşındayken, ona Fransa'yı kurtarmasını söyleyen birtakım sesler işittiğini söyledi. Tanrı inancı çok güçlü olan Jeanne, bu seslerin Tanrıdan geldiğine inandı ve Fransa'yı kurtarmak için ailesini ve kasabasını terk etti. Amacı Orléans'ı kuşatarak Fransa'yı İngiliz işgalinden kurtarmak ve VII. Charles'a taç giydirip onu kral ilan etmekti. Bu amaçlarını yerine getirdi. Paris'i de almak için yola çıktığında VII. Charles'ın desteğini görmedi ve İngilizlere esir düştü. Jeanne D'arc, uzun bir yargılamanın sonunda 1431 yılında başta Kiliseyi tanımama olmak üzere, içinde büyücülük, cadılık ve erkek kıyafetleri giymek gibi suçlar da bulunan 12 madde ile suçlandı ve ateşte yakılarak öldürüldü. Ayrıntılı bilgi için bkz., Tuğçe Gözde Yılmaz, Tarihsel - Tiyatral Kişilik İlişkisinin Jeanne D'arc Konulu Oyunlara Yansıması, (Dokuz Eylül Üniversitesi Güzel Sanatlar Enstitüsü Sahne Sanatları Anabilim Dalı, Yayınlanmamış Yüksek Lisans Tezi), İzmir 2010, s.126130.

${ }^{42}$ Jeanne D'arc kruvazörü 2 Ağustos 1934 tarihinde denize indirildi. 6.496 ton ağırlığında, 160 metre boyunda, 18 metre genişliğindeydi. 8 adet 6.1 inçlik, 4 adet 3 inçlik, 6 adet 40 milimetrelik ve 20 adet 20 milimetrelik topu vardı. 506/643 mürettebat görev yapmaktayd1. Bkz., T.Fred Jane's, All The World Fighting Ships 1949-1950, Francis E., McMurtie, London, England 1950, s.180; Cumhuriyet, 16 Ekim 1946, s.2.

${ }^{43}$ Jeanne D'arc kruvazörünün İstanbul ziyareti ile ilgili örnek bir yazışma için bkz., Lalahan Deniz Genel Arşiv Müdürlüğ̈̈ (LDGAM), Kutu No (Ktn.):1935-29, Gömlek No (Gmn.):16, Belge No (Bn.):2, Tarih (T.):15 Nisan 1935. 
Cumhuriyet Devri Diplomat Naaşlarının Nakillerinde Savaş Gemilerinin Kullanılması Örnekleri...

Jeanne D'arc kruvazörünün karşılanması ve ziyaret sırasında Fransız denizcilere eşlik edilmesi görevini yerine getiren Kocatepe muhribi, Jeanne D'arc kruvazörünün 5 Haziran günü saat 10:00'da İstanbul'dan ayrılması sonrası, Rus kruvazörü Chervonaya Ukraina'nın karşılanması görevini ald1. ${ }^{44}$

Kocatepe muhribi Chervonaya Ukraina kruvazörünü karşılama görevi için 6 Haziran günü saat 23:00'da demirli olduğu Haydarpaşa limanında hareket hazırlıklarına başladı. ${ }^{45}$ 7 Haziran günü saat 03:02'de Kocatepe muhribi limandan demir alarak hareket etti. ${ }^{46} \mathrm{Gemi}$, tören ile ilgili son direktifleri almak üzere Heybeliada'da bulunan gemi komutanı Binbaşı Kemal Enginol' ${ }^{47}$ almak üzere Heybeliada'ya yanaştı. Komutanın alınmasından sonra saat 04:10'da Heybeliada'dan demir alındı. Saat 04:55'te Ahırkapı, saat 05:51'de Rumeli Kavağ 1 Feneri geçildi. Saat $06: 12$ 'de Chervonaya Ukraina kruvazörünün dümen suyuna girildi. ${ }^{48}$ Ardından gemiler saat 07:32'de Büyükdere önüne demirledi. Chervonaya Ukraina kruvazörü Büyükdere'den hareket etmeden hemen önce Sovyet Rusya Büyükelçiliği Ataşemiliteri Kloçko ve yardımcısı Rigerman gemiye geldi. Saat 11:50'ye kadar Büyükdere'de bekleyen gemiler demir alarak, Haydarpaşa limanına doğru ilerlemeye başladı. Gemiler saat 12:30'da Dolmabahçe önüne ulaştı. Kızkulesi önüne geldiklerinde ise Chervonaya Ukraina kruvazörü top atışıyla İstanbul'u selamladı. Bu atışa Selimiye Kışlasından yapılan top atışıyla karşılık verildi. Tam bu sırada Vali Yardımcısı Rükneddin, Kolordu Komutanı General Halis, Merkez Komutanı General Fehmi, Harp Filosu Komutan Vekili Albay Şükür Okan ${ }^{49}$, Filotilla Komodor Vekili Yarbay Sait Halman ${ }^{50}$, Emniyet Müdürü Fehmi, Belediye Başkanı Yardımcısı Hamid, Sovyet Büyükelçiliği Başkatibi Poleykof, Dışişleri Bakanlığı Özel Kalem Memurlarından Nejad, Cumhuriyet Halk Partisi İl İdare Heyeti Başkan Yardımcısı Ali Rıza, gazeteciler, Sovyet ticaret temsilcileri ve daha birçok kişi Şirket-i Hayriye'nin 57 Numaralı Tarabya vapuru ${ }^{51}$ ile naaşı karşılamak üzere Deniz Yolları İdaresi'nin Tophane'deki rıhtımından hareket etti. Vapurda vilayet, parti, halkevi, Sovyet Büyükelçiliği, Sovyet ticaret temsilciliği ve belediye adına getirilmiş çelenkler de bulunuyordu. Haydarpaşa limanına ulaşan gemilerden Chervonaya Ukraina kruvazörü saat 12:55'te Haydarpaşa dalgakıranının biraz açığına, Kocatepe muhribi de

\footnotetext{
${ }^{44}$ LDGAM., Gemi Jurnalleri Bölümü (Gjb.), Kocatepe Muhribi Gemi Jurnali (KMGJ.), Kayıt No (Kytn.): 34994, T.: 30-31 Mayıs, 1, 2, 3, 4, 5 Haziran 1935.

${ }^{45}$ LDGAM., Gjb., KMGJ., Kytn.: 34994, T.: 6 Haziran 1935.

${ }^{46}$ LDGAM., Gjb., KMGJ., Kytn.: 34994, T.: 7 Haziran 1935.

${ }^{47}$ Kocatepe muhribi komutanı Binbaşı Kemal Enginol, 30 Ağustos 1935 tarihi itibariyle Hücumbot Filotillası Komutanı olana kadar görevine devam etti. Bkz., LDGAM., Ktn.:1935-57, Gmn.:89, Bn.:8, T.:2 Haziran 1935; Ersan Baş, Türk Tarihinde Yavuz Zırhlısının Rolü, Deniz Basımevi Müdürlüğü, İstanbul 2008, s.205.

${ }^{48}$ Dümen Suyu (Wake - Wake current - Back water): Hareket halindeki ileri yolda bir teknenin kıç tarafinda bıraktığı iz, karışık su. Bkz., Seri, age, s.173.

${ }^{49}$ Harp Filosu Komutan Vekili Albay Şükür Okan bu göreve 24 Teşrinisani 1931 tarihinde atandı. Bu görevi 30 Eylül 1935 tarihinde atandığı Donanma Komutan Vekilliği görevine kadar sürdürdü. Kendisi 30 Ağustos 1935 tarihinde Tuğamiral, 30 Ağustos 1936 tarihinde Tümamiral ve 30 Ağustos 1939 tarihinde Koramiral oldu. Bkz., LDGAM., Şükür Okan Şahsi Dosyası.

${ }^{50}$ Filotilla Komodor Vekili Yarbay Sait Halman bu göreve 10 Kanunisani 1934 tarihinde atandı. Bu görevi 12 Teşrinievvel 1935 tarihinde atandığı Deniz Müsteşarlı̆̆ı Vekilliğine kadar sürdürdü. Kendisi 30 Ağustos 1935 tarihinde Albay, 11 Teşrinievvel 1939 tarihinde Tuğbay, 30 Ağustos 1940 tarihinde Tuğamiral ve 30 Ağustos 1942 tarihinde Tümamiral oldu. Bkz., LDGAM., Sait Halman Şahsi Dosyas1.

5157 Numaralı Tarabya vapuru 1906 tarihinde Glasgow'da Fairfield Ship Cop. tersanesinde yolcu vapuru olarak yapıldı. Teknesi çelik sactı. 122 gros ton ağırlığında, 30,4 metre boyunda, 5,9 metre enindeydi ve 1964 yılında hizmet dışı bırakıldı. Bkz., Eser Tutel, Seyr-i Sefain Öncesi ve Sonrası, İletişim Yayınevi, İstanbul 2000, s.214, https://www.sehirhatlari.istanbul/tr/kurumsal (E.T. 11.11.2019)
} 
bu geminin yakınına saat 13:02'de demirledi. 57 Numaralı Tarabya vapuru ise Chervonaya Ukraina kruvazörünün bordasına yanaşt1. ${ }^{52}$

57 Numaralı Tarabya vapuru yanaşma manevrasını tamamladıktan sonra vapurda bulunan sivil ve asker şahıslar, Chervonaya Ukraina kruvazörüne geçti. Chervonaya Ukraina kruvazöründe Visamiral Ralli ve Sovyet Dışişleri Komiserliği siyasal kısım memurlarından Miller, Türk heyetini büyük bir samimiyetle karşıladı. Visamiral Ralli ve Chervonaya Ukraina kruvazörü komutanı Kuznitsov Türk heyetine Sovyet Hükümeti adına taziyelerini bildirdi. Bu sırada Vasıf Çınar'ın naaşı Türk Bayrağına sarılı olarak geminin kıç güvertesinde bulunuyordu. Güvertenin her tarafı çelenklerle kaplıydı. Ayrıca kırmızı atlas üzerine beyaz harflerle Türkçe olarak yazılmış iki levha yer alıyordu. Bunlardan birisinde "Büyük Türkiye Cumhuriyetinin, Büyük Elçisi muhterem Vasıf Çınar'a ebedi hürmetler." ve diğerinde de "Sovyet Şuraları İttihadı kıymetli dost, Türkiye Büyük Elçisi Vasıf Çınar'ın ebedi hatırasını tebcil ${ }^{53}$ eder." ibareleri vard1.

Gemideki taziye takdim merasimi bittikten sonra hep birlikte merhumun tabutunun bulunduğu yere gidildi ve burada 3 dakika sessizce duruldu. Sessizlik duruşunun bittiğini bildiren zil sesinden sonra, Chervonaya Ukraina kruvazöründe bulunan askeri bando cenaze marşları çalmaya başladı. Bu marşlar da ayakta ve büyük bir sessizlik içinde dinlendi. Ardından on kadar Sovyet bahriyelisi Vasıf Çınar'ın naaşını yavaş yavaş kaldırdılar ve ağır adımlarla 57 Numaralı Tarabya vapuruna götürmeye başladılar. Bu sırada askeri bando marş çalmaya devam etti. Tabut vapura konulurken Türk heyetiyle birlikte Visamiral Ralli ve Chervonaya Ukraina kruvazörü komutanı Kuznitsov da vapura geçti. Vapur hareket ederken Chervonaya Ukraina kruvazörü top atışı yaptı. Sonrasında 57 Numaralı Tarabya vapuru doğruca Haydarpaşa rıhtımına yanaştı. Burada bir bando, askeri tören kıtası, bir polis müfrezesi ve çok sayıda vatandaş yer almıştı. İlaveten Muallimler Birliği, İstanbul Kültür Müdürü Mehmed Emin, yüzlerce öğretmen ve öğrenci eski Milli Eğitim Bakanına taziyelerini sunmak için bekliyordu.

Cenaze alayı saat $14: 15$ 'te gara giriş yaptı. Bando matem marşları çalarken, kırmızı beyaz bir atlas yastık üzerinde bulunan Vasıf Çınar'ın İstiklal Madalyası önde olduğu halde, tabut özel vagona nakledildi. Tren yavaş yavaş harekete hazırlandı ve saat 14:30'da Ankara'ya doğru hareket etti. ${ }^{54}$

\subsection{Rus Kruvazörü Chervonaya Ukraina'nın Açı Denizde Kocatepe Muhribi Tarafından Uğurlanması}

Cenaze merasiminin ardından Visamiral Ralli ve Chervonaya Ukraina kruvazörü komutanı Kuznitsov saat 16:30'da İstanbul Valiliğine gelerek Vali yardımcısı Rükneddin'i ziyaret etti. Ziyaretin tamamlanmasından sonra bu ziyaretin iadesi maksadıyla Vali yardımcısı Rükneddin, Chervonaya Ukraina kruvazörüne iadei ziyarette bulundu. ${ }^{55}$

Karşılıklı ziyaretlerin tamamlanmasının ardından, daha önceden planlandığı gibi Chervonaya Ukraina kruvazörünün Rusya’ya dönüş zamanı geldi. Gemiyi, yine daha önceden yapılan plana istinaden Kocatepe muhribi uğurlayacaktı. 7 Haziran günü Kocatepe muhribi saat 21:35'te Haydarpaşa' dan demir aldı. Saat 21:38'de de Chervonaya Ukraina kruvazörü hareket

\footnotetext{
${ }^{52}$ LDGAM., Gjb., KMGJ., Kytn.: 34994, T.: 7 Haziran 1935; Cumhuriyet, 08 Haziran 1935, s.1, 7; Ulus, 08 Haziran 1935, s.1.

53 Tebcil: Ululama, ağırlama. Bkz., Ferit Devellioğlu, Osmanlıca-Türkçe Ansiklopedik Lûgat, Aydın Kitabevi, Ankara 1998, s.1046.

${ }^{54}$ Cumhuriyet, 07 Haziran 1935, s.1, 8; Ulus, 07 Haziran 1935, s.1; Cumhuriyet, 08 Haziran 1935, s.1, 7; Akşam, 08

Haziran 1935, s.1, 4; Kurun, 08 Haziran 1935, s.1, 12, 16; Ulus, 08 Haziran 1935, s.1, 2, 5.

${ }^{55}$ Cumhuriyet, 08 Haziran 1935, s.7; Akşam, 08 Haziran 1935, s.4.
} 
Cumhuriyet Devri Diplomat Naaşlarının Nakillerinde Savaş Gemilerinin Kullanılması Örnekleri...

etti. İki gemi birlikte Boğaz çıkışına doğru ilerledi. Kocatepe muhribi Fener Dubası önüne kadar Chervonaya Ukraina kruvazörüne refakat etti ve saat 23:45'te geminin dümen suyundan ayrılarak 8 Haziran günü saat $01: 10$ 'da Haydarpaşa önüne demirledi. ${ }^{56}$

\subsection{Naaşın Ankara'ya Nakledilmesi ve Ankara'da Yapılan Cenaze Merasimi}

Vasıf Çınar'ın naaşını taşıyan tren, Haydarpaşa Garından 7 Haziran günü saat 14:30'da Ankara'ya doğru hareket etmişti. Tren, 8 Haziran günü saat 14:00'e doğru Ankara Garına ulaştı. Naaşı Ankara Vali Yardımcısı Salahaddin, Merkez Komutanı Albay Demir Ali ve Emniyet Müdürü Salih ile protokol memurları karşıladı. Ardından naaş, vagondan çıkarılarak törenin yapılacağı istasyon meydanına getirildi ve burada siyah örtülü kürsüye konuldu. Tabut, vagondan istasyon meydanına kadar asker ve polis müfrezelerinin katıldığ merasim ile nakledildi.

Merasimde hazır bulunacaklar saat 15:00'ten itibaren istasyona gelmeye başladı. Tören başlamadan önce; Meclis Başkanı Abdülhalik Renda, Genelkurmay Başkanı Mareşal Fevzi Çakmak, Bakanlar Kurulu üyeleri, Cumhurbaşkanlığı Genel Sekreter Vekili, Başyaver, Cumhuriyet Halk Partisi Genel Sekreteri Recep Peker, Meclis Başkan Vekilleri ve üyeleri, kordiplomatik, Sayıştay üyeleri ve Bakanlık ileri gelenleri Türk bayrağına sarılı ve dört süngülü asker tarafından beklenen tabutun etrafında yerlerini aldı. Başbakan İsmet İnönü rahatsızlığ dolayısıyla törende hazır bulunamadı.

Tören saat 15:40'ta Dışişleri Bakanı Tevfik Rüştü Aras'ın yaptığı konuşmayla başladı. Daha sonra tabut, altı siyah atın çektiği ve defne dallarına sarılmış bir top arabasına konuldu ve ardından cenaze korteji hareket etti. Kortejin en önünde Merkez Komutanı Albay Demir Ali yürümekteydi ve onu flamalarına siyah kurdeleler bağlanmış bir süvari bölüğ̈̈, bando, piyade ve polis müfrezeleri takip etmekteydi. Bunlardan sonra başta Cumhurbaşkanı Atatürk'ün ve Cumhuriyet Halk Partisinin altı oklu çelenkleri ile birçok yerden gönderilmiş ve sayısı yüze varan çelenkler bulunuyordu. Bunların arkasından da Vasıf Çınar'ın tabutunu taşıyan ve iki yanında Dışişleri Bakanlığı memurlarının bulunduğu top arabası geliyordu. Arabayı da başta Vasıf Çınar'ın aile efradı olmak üzere Meclis Başkanı Abdülhalik Renda, Bakanlar Kurulu üyeleri, Cumhurbaşkanlığı Genel Sekreter Yardımcısı, Başyaver ve Muhafız Alayı Komutanı, kordiplomatik, milletvekilleri ve diğer zevat takip etmekte ve onlardan sonra da bir piyade ve süvari kıtası gelmekteydi.

Bandonun çaldığı cenaze marşı eşliğinde ilerleyen kortej, istasyondan itibaren geçilecek olan caddeler boyunca biriken büyük bir kalabalığın arasından geçerek, Dışişleri Bakanlığı önüne geldi ve tabut burada top arabasından indirilerek cenaze arabasına nakledildi. Törene katılanlar bundan sonra naaşı Cebeci'ye kadar otomobillerle takip etti. Vasıf Çınar'ın tabutu Cebeci'de cenaze aracından indirildiği zaman bir asker ve polis müfrezesi tarafından selamlandı ve hazırlanan mezara konuldu. Defin işlemi tamamlandıktan sonra başta Meclis Başkanı Abdülhalik Renda olmak üzere merasime iştirak edenler, Vasıf Çınar'ın aile efradına bir defa daha baş sağlığında bulundu. ${ }^{57}$

\footnotetext{
${ }^{56}$ LDGAM., Gjb., KMGJ., Kytn.: 34994, T.: 7-8 Haziran 1935.

${ }^{57}$ Cumhuriyet, 09 Haziran 1935, s.1, 6; Ulus, 09 Haziran 1935, s.1, 3, 4; Akşam, 09 Haziran 1935, s.2; Kurun, 09 Haziran 1935, s.1, 9.
} 


\section{Amerika Büyükelçisi Minür Ertegün'ün Naaşının Türkiye’ye Getirilmesi}

\subsection{Minür Ertegün'ün Hayatı ve Amerika Büyükelçiliği Döneminde Türkiye- Amerika İlişkileri}

M. Münir Ertegün 1883 yılında İstanbul'da doğdu. Babası Mehmet Cemil Bey Evkaf Nazırlığı yaptı. Annesi Ayşe Hamide Hanım ise Özbekler Tekkesi Şeyhi İbrahim Edhem Efendi'nin kızıydı. Ertegün 1908 yılında İstanbul Darülfünunu'nun hukuk bölümünü bitirdi ve Dış İşlerinde memur olarak işe başladı. Ardından İstanbul hükümetlerinde hukuk danışmanlığ görevine geçti. 1917 tarihinde Şirket-i Hayriye yöneticilerinden Rüstem Bey'in kızı, Hayrünnisa Hanım ile evlendi.

İtifak Devletleri ile Rusya arasında yapılan Brest Litovsk görüşmelerinde Osmanlı heyetinde yer aldı. Milli Mücadele döneminde Mustafa Kemal Paşa'yla görüşmek üzere İstanbul Hükümeti tarafindan gönderilen Ahmed İzzet Paşa heyetinde hukuk müşaviri olarak bulundu. Bu görüşme sonrasında Milli Mücadele hareketine katıldı. Savaş sonrasında hukuk danışmanı olarak Lozan Barış Görüşmelerine iştirak etti. Cumhuriyet devrinde Milletler Cemiyeti'nde Türk gözlemci olurken ve bu göreve ilaveten Bern ortaelçisi olarak İsviçre'de görev verildi. Daha sonra Paris ve Londra'da büyükelçilik görevlerini yürüttü. Mehmet Münir Ertegün, 1927-1934 yılları arasında Amerikan Büyükelçiliği görevini yürüten Ahmet Muhtar Beyden 18 Haziran 1934 tarihinde görevi devralarak, vefat ettiği 1 Kasım 1944 tarihine kadar devam ettirdi. Özellikle ABD Başkanı Franklin D. Roosevelt ile yakın ilişkileri oldu. ${ }^{58}$

Münir Ertegün'ün Büyükelçilik görevine başladığı yıllarda, II.Dünya Savaşı'nın temelleri atıliyordu. Avrupa'da 1930'lu y1lların sonunda gerginlikler yükselirken, Türkiye'nin kendisi için tehdit olarak gördüğü ülkeler değişiyordu. 1934 yılı ile birlikte Türkiye en büyük tehlike olarak İtalya'yı görmeye başladı. 1935-1936 yıllarına gelindiğinde İtalya, Doğu Akdeniz çevresinde büyük problem olmaya başlamış ve Türkiye tehditkar yaklaşımlar karşısında Batılı Devletlerle ilişkilerini güçlendirmeye karar vermişti. ${ }^{59}$ Özellikle İtalya'nın 1936 yılında daha önce işgal ettiği On İki Ada'da çeşitli askeri hareketliliklere imza atması Türkiye'nin endişelerini artırdı. Bunun üzerine 1932 yılında Milletler Cemiyeti'ne girmiş olan, 1934 yılında Balkan Antantı'nı yapan Türkiye, 1936 yılında da Montrö Boğazlar Sözleşmesi ile hem kendi sınırları içerisindeki Boğazların kontrolünü sağladı hem de Dünya Devletlerine karşı egemenlik haklarını kabul ettirdi. Bu gerginliklerin yaşandığı ve II.Dünya Savaşına gidilen tarihlerde, Türkiye Akdeniz'in güvenliğinin sağlanması maksadıyla 1937 tarihli Nyon Konferansı süreci içindeyken, Türk-Amerikan ilişkileri ticari boyutta seyrediyordu. ${ }^{60}$

Münir Ertegün, Washington'da göreve başladıktan hemen sonra Meksika Elçisi olarak da görevlendirildiği için Meksika'ya gitti. Meksika Cumhurbaşkanı'na güven mektubunu sundu. Burada edindiği izlenimleri rapor olarak Türkiye'ye gönderdi. 1939 y1lında New York'ta tertiplenen Dünya Fuarı'nda Türkiye'nin de bulunması maksadıyla Türkiye'den kumaş, deri, kağıt ve metal eşyalar getirilmesini sağladı.

Münir Bey göreve başladıktan kısa zaman sonra, II. Dünya Savaşı başladı. Türkiye, savaşın başında savaşan devletler arasında, denge siyaseti izlemeye çalıştı. Bu süreçte zaman zaman İngiltere'ye yanaşılırken hiçbir zaman Almanya ve Sovyetler Birliği'nden uzaklaşılmadı.

\footnotetext{
${ }^{58}$ Fatma Öztürk, Mehmet Münir Ertegün'ün Hayatı ve Türk Yakınçağı’ndaki Yeri, (Uşak Üniversitesi Sosyal Bilimler Enstitüsü, Yayımlanmamıș Doktora Tezi), Uşak 2016, s.7, 8, 9, 13, 28, 40, 41, 49, 50, 84, 97, 102, 109; http://washington.emb.mfa.gov.tr/Mission/MissionChiefHistory (E.T. 05.04.2020); Bilal N. Şimşir, Bizim Diplomatlar, Bilgi Yayınevi, Ankara 1996, s.293- 317; Vakit, 04 Nisan 1946, s.3; Tanin, 05 Nisan 1946, s.1.

${ }^{59}$ Armaoğlu, age, s.335.

${ }^{60}$ Armaoğlu, age, s.342; Oran, age, s.75, 273, 313.
}

History Studies 
Cumhuriyet Devri Diplomat Naaşlarının Nakillerinde Savaş Gemilerinin Kullanılması Örnekleri...

Tarafsız bir ülkenin büyükelçisi olarak Münir Ertegün'de Amerika'da denge siyaseti izliyordu. Temel amacı; Türkiye ile Amerika arasındaki siyasi, kültürel, askeri ve ekonomik boyuttaki ilişkilerin geliştirilmesi oldu. Özellikle savaş başladıktan sonra Münir Bey, Türkiye'ye askeri malzeme sağlanması konusunda yoğun bir mesai harcadı. Bu süreçte Türkiye'nin Almanya ile kurduğu askeri ve ekonomik ilişkiler, Ertegün'ü zor durumda bıraktı. Ancak Münir Bey, donanımlı bir diplomat ve iyi bir hukukçu olarak bu sorunu da başarıyla yönetmesini bildi. ${ }^{61}$

\subsection{Minür Ertegün'ün Vefat Etmesi ve Naaşının Türkiye'ye Nakledilme Süreci}

Türkiye, savaş sonrasında artan Sovyetler Birliği tehlikesine karşı, ABD’nin desteğini arkasına almaya çalıştı. Bu süreçte Amerika'nın Türkiye'ye olan yakınlığının arttığını gösteren sembol olay, Amerika'nın Türkiye Büyükelçisi Münir Ertegün'ün vefatı sonrası, naaşının Amerikan donanmasının en önemli parçalarından biri olan Missouri zırhlısıyla ${ }^{62}$ İstanbul'a getirilmesi oldu. ${ }^{63} \mathrm{Bu}$ iş için seçilen Missouri zırhlısı da simgesel anlam taşıyan bir gemiydi. Çünkü II.Dünya Savaşı sonunda Japonya, teslimiyet belgesini, 2 Eylül 1945 tarihinde Tokyo limanında bulunan Missouri zırhlısında General Mac Arthur'un huzurunda imzalamıştı. ${ }^{64}$ Böylesine önemli bir geminin bu şekilde görevlendirilmesi, tamamen Amerika'nın Sovyetler Birliği'ne karşı güç gösterisinde bulunma isteğiyle açıklanabilir. ${ }^{65}$ Ziyaretin gerçekleşmesi sonrası için de "Türkiye'nin Sovyetler Birliği karşısındaki yalnızlığı sona ermiştir.” yorumu getirilebilir. ${ }^{66}$

Ertegün'ün naaşının bir Amerikan savaş gemisiyle Türkiye'ye nakledilmesi fikrinin ortaya çıkışı ile ilgili çeşitli görüşler vardır. İlk görüş Ertegün'ün vefatından hemen sonra, diplomatik geleneklere uygun bir şekilde naaşın bir savaş gemisi ile Türkiye'ye gönderilmesini Türkiye Cumhuriyeti Devleti'nin Amerika Birleşik Devletlerinden talep ettiğidir. Yapılan bu talep ABD hükümeti tarafindan olumlu karşılanmış, savaş koşulları bu işe imkan sağlamamıştır. ${ }^{67}$

Diğer bir görüş; bu fikrin 1945 senesinin sonlarına doğru Türkiye’nin Amerika Büyükelçisi Hüseyin Ragıp Baydur'dan geldiğidir. Baydur'da bu fikrin oluşmasını sağlayan olay ise İngiliz Büyükelçisi Lord Lothian (Philip Kerr)'ın naaşının bir Amerikan savaş gemisiyle İngiltere'ye

${ }^{61}$ Öztürk, agt, s.109-127.

${ }^{62}$ Missouri zırhlısı, General Electric Company tarafindan New York Navy Yard'da 6 Kanunisani 1941 tarihinde kızağa konmuş, 11 Haziran 1944 tarihinde yapımı tamamlanmıştır. Ağırlığ1 45.000 ton olup, tam yüklü ağırlığ 52.000 tondur. Boyu 268 metre, eni 33 metre, çektiği su 11 metredir. Ana bataryas1 9 adet 406 milimetrelik ağır toptan oluşur. Bu toplar 2000 librelik mermileri 20 milden uzak mesafeye atabilir. Bu topların ikisi başta biri kıçta olup, her biri 2000 ton ağırlığında 3 tarete üçüzlü olarak monte edilmiştir. Gemide 2 "catapult" (uçakların kısa mesafede havalanabilmesi için onları firlatan cihaz) ve 4 uçak vardır. Sürati 30-35 deniz mili civarındadır. Ayrıntılı bilgi için bkz., T.Fred Jane's, All The World Fighting Ships 1944-1945, Francis E., McMurtie, London, England 1945, s.448; "Amerikan Filosunun İstanbul'u Ziyareti”, Deniz Kuvvetleri Dergisi, C.58, S.377, Ankara 1946, s.136137; Cumhuriyet, 07-09-14 Nisan 1946, s.2; Cumhuriyet, 09 Nisan 1946, s.2; Cumhuriyet, 14 Mart 1946, s.3; Vakit, 04 Nisan 1946, s.2.

${ }^{63}$ Barış Ertem, “İkinci Dünya Savaşı Sırasında Türkiye Sovyetler Birliği İlişkileri ve Türkiye’nin Amerika Birleşik Devletleri ile Yakınlaşmasına Etkileri”, Turkish Studies Dergisi, Volume 8/7, Ankara 2013, s.176-177; Yavuz Güler, "II. Dünya Harbi Sonrası Türkiye-Amerikan İlişkileri (1945-1950)", Ahi Evran Üniversitesi Kırşehir Eğitim Fakültesi Dergisi, C.V, S.II, Kırşehir 2004, s.211-214.

${ }^{64}$ Cüneyt Akalın, Soğuk Savaş ABD ve Türkiye - 1 Olaylar - Belgeler (1945 -1952), Kaynak Yayınları, İstanbul 2003, s.494-495.

${ }^{65}$ Cumhuriyet Ansiklopedisi 1923-2000, C.II (1941-1960), Yap1 Kredi Yayınları, İstanbul 2003, s.102. Türk Deniz Kuvvetlerinde bu dönemde görev yapan subaylar da Missouri zırhlısının böyle bir görev almasını anlamaya çalışmıştır. Bkz., E.Dz.Kur.Alb. Celal Denizalp’in Anıları, Donanma Komutanlığı Deniz Tarihi Arşivi Müdürlüğü Yayın1, Kocaeli 2002, s.58.

${ }^{66}$ İlhan Tekeli- Selim İlkin, Dış Siyaseti ve Askeri Stratejileriyle İkinci Dünya Savaşı Türkiyesi, Cilt I, İletişim Yayınları, İstanbul 2014, s.537.

${ }^{67}$ Cüneyt Akalın, "Missouri’nin Ziyaretinin Tarihsel Anlamı”, Yakın Dönem Türkiye Araştırmaları Dergisi, Y.II/2003, S.III, s.4 
nakledilmesidir. Bu gelişme üzerine Baydur, hükümetten izin alarak, Amerikan Dışişleri Bakanlığına başvurmuştur. ${ }^{68}$

Ertegün'ün naaşının bir savaş gemisiyle Türkiye'ye nakledilme fikrinin ortaya atılması ile ilgili bir diğer görüş ise fikrin sahibinin o dönemde ABD Dışişleri Bakanlığ1 Müsteşarlığ 1 görevini yürüten, Dean Acheson olduğudur. Buna göre Acheson, İngiliz Büyükelçisi Lord Lothian'ın naaşının İngiltere'ye nakledilmesine benzer bir şekilde, Ertegün'ün naaşının da Türkiye'ye nakledilmesi konusunu 25 Ocak 1946 tarihinde Başkan Truman'a açmıştır. Kabul gören bu fikir, Başkan Truman tarafından 4 Mart 1946 tarihinde başkanlık treniyle Fulton'a giderken Churchill'e de açıklanmıştır. ${ }^{69}$

Amerika'nın Türkiye Büyükelçisi Münir Ertegün'ün naaşının İstanbul'a getirilmesi için, Missouri zırhlısı ve Power torpido muhribine ${ }^{70}$ gerekli Bakanlar Kurulu izni, 7 Mart 1946 tarihinde verildi. ${ }^{71} \mathrm{Bu}$ tarihten sonra gemilerin İstanbul'a gelişi ile ilgili haberler gazetelerde yer almaya başladı. ${ }^{72}$ Yapılan ilk planda Providence kruvazörünün ${ }^{73}$ gelmesi düşünülmemişti ve İstanbul'a gelişi için Bakanlar Kurulu izni alınmamıştı. Providence kruvazörü için gerekli izin, 25 Mart 1946 tarihinde alındı. ${ }^{74}$ Kararlaştırılan programa göre Missouri zırhlısının 21 Mart'ta New York'tan ayrılması tasarlanmıştı. ${ }^{75}$

Amerika'nın Türkiye Büyükelçisi Münir Ertegün, 11 Kasım 1944 tarihinde Washington'da vefat etmişti ve naaşı Darlington Milli Mezarlığındaydı. Buradan alınacak naaş New Jersey Bayonne'e kadar trenle getirilerek Missouri zırhlısina nakledilecek ve 21 Mart 1946 tarihinde Cebelitarık istikametine doğru yola çıkılacaktı. Avrupa'daki Amerikan Deniz Kuvvetleri'nin Komutanı Oramiral Hewitt, Cebelitarık'ta zırhlıya binecek ve İstanbul'a gelecekti. ${ }^{76}$

${ }^{68}$ Gül İnanç, “US Missouri Zırhlısı'nın İstanbul Ziyareti ve Soğuk Savaş Diplomasisinde Türkiye, 1946” Toplumsal Tarih, S.191, İstanbul 2009, s.51,52.

${ }^{69}$ Nuri Karakaş, Türk-Amerikan Siyasi İlişkileri (1939-1952), Atatürk Araştırma Merkezi Yayını, Ankara 2013, s.231-232.

${ }^{70}$ Power torpido muhribi: Gearing sınıfı destroyerdir. "Bath Iron Works, Bath, Maine" tarafından 26 Şubat 1945 tarihinde imaline başlanmış, 30 Haziran 1945 tarihinde tamamlanmıştır. Uzunluğu 119,02 metre, en geniş noktası 12,45 metredir. Kasım 1960'tan Ocak 1962'ye kadar modernize edilmiştir. Eylül 1977'de hizmet dişı bırakılmış ve Ekim ayında Tayvan'a satılmıştır. Ayrıntılı bilgi için bkz., T.Fred Jane's, All The World Fighting Ships 1946-1947, Francis E., McMurtie, London, England 1947, s.365; https://en.wikipedia.org/wiki/USS_Power_(DD-839) (E.T. 15.04.2020).

${ }^{71}$ Cumhurbaşkanlığ Dosya No (Dosn.):18, Sira No (Sn.):8.

72 Cumhuriyet, 08 Mart 1946, s.1; Vakit, 09 Mart 1946, s.1. Münir Ertegün'ün naaşının İstanbul'a getirilmesi ilgili haberler Amerikan gazetelerinde Türk gazetelerinden daha önce yer aldı. Örnek gazeteler için bkz., Evening Star, 7

Mart 1946, s.11; The Wilmington Morning Star, 7 Mart 1946, s.2, 13.

${ }^{73}$ Providence kruvazörü: Cleveland sınıfı hafif kruvazördür. Bethlehem Shipbuilding Corporation'ın Fore River Tersanesi'nde 27 Temmuz 1943 tarihinde inşaasına başlanmış, 15 Mayıs 1945 tarihinde hizmete girmiştir. Uzunluğu 185.95 metre, en geniş noktası 20,22 metredir. 1957'den 1959'a kadar süren çalışmalarla güdümlü füze kruvazörüne dönüştürülmüştür. 15 Temmuz 1980 tarihinde hurdaya çıkarılmıştır. Ayrıntılı bilgi için bkz., T.Fred Jane's, All The World Fighting Ships 1946-1947, s.361; https://en.wikipedia.org/wiki/USS_Providence_(CL-82) (E.T. 15.04.2020).

${ }^{74}$ Verilen izin belgesiyle, Amerikan gemilerinin Türk karasularında ve İstanbul'da telsizle muhabere edebilmelerine imkan tanınmıştı. Bkz., CDAB., Fn.:30.18.1.2., Ktn.:110, Dosn.:22, Sn.:13. Missouri zırhlısı, Providence kruvazörü ve Power torpido muhribi, 1930 yılında Çanakkale Boğazı'nı geçerek İstanbul'a gelen Chester kruvazöründen sonra İstanbul'u ziyaret eden ilk gemilerdi. Bkz., Vakit, 05 Nisan 1946, s.1; Tanin, 05 Nisan 1946, s.4. Chester kruvazörü 15 Eylül 1930 tarihinde İstanbul'a geldi. Ağırlığ 10.000 ton olup, 9 adet 20 santimetrelik topları olan gemi 32 deniz mili sürat yapabilmekteydi. Ayrıntılı bilgi için bkz., Cumhuriyet, 16 Eylül 1930, s.3.

${ }^{75}$ Son Posta, 09 Mart 1946, s.1,7; Cumhuriyet, 08 Mart 1946, s.1.

${ }^{76}$ Cumhuriyet, 18 Mart 1946, s.1; Cumhuriyet, 19 Mart 1946, s.3. Amiral Hewitt'in özgeçmişi için bkz., Son Posta, 04 Nisan 1946, s.4; Vakit, 04 Nisan 1946, s.3; The Sphere, 13 Nisan 1946, s.16. 
Cumhuriyet Devri Diplomat Naaşlarının Nakillerinde Savaş Gemilerinin Kullanılması Örnekleri...

Yapılan plana sadık kalındı ve Missouri zırhlısı, Providence kruvazörü ve Power torpido muhribiyle 21 Mart'ta İstanbul'a doğru hareket etti. ${ }^{77} \mathrm{Bu}$ sirada Amerikan gemilerini karşılamak için 5 günlük bir program hazırlandı. ${ }^{78}$

Gemiler 30 Mart 1946 tarihinde Cebelitarık'a ulaştı. ${ }^{79} 31$ Mart'ta Cebelitarık'tan geçen zırhlılar Akdeniz'e girdi. ${ }^{80}$

\subsection{Amerikan Gemilerinin Açık Denizde Karşılanması ve İstanbul'da İcra Edilen Cenaze Merasimi}

Münir Ertegün'ün naaşının bulunduğu Missouri zırhlısı ile bu gemiye refakat eden Providence kruvazörü ve Power torpido muhribini karşılama ve refakat etme görevi Yavuz kruvazörü ile Demirhisar, Sultanhisar ve Muavenet muhriplerine verildi. Bu görevi alan gemiler her türlü hazırlıklarını yapmış olarak 2 Nisan 1946 tarihinde Gölcük'te harekete hazır olarak beklemeye başladı. Aynı gün Demirhisar ve Sultanhisar muhripleri saat 08:40'da, Muavenet muhribi saat 08:50'de ve Yavuz kruvazörü ise saat 09:00'da limandan demir aldı. Gemiler İstanbul'a doğru seyirlerine devam ederken, ilki saat 10:30 ile saat 12:30 aras1, ikincisi saat 13:30 ile saat 16:15 arasında olmak üzere; mesafe ölçümü, dönüş manevraları, muhriplerin Yavuz kruvazörüne hücumları ve hava hücumlarından sakınma gibi eğitimler gerçekleştirildi. Eğitimlerin bitmesini müteakip Dolmabahçe Sarayı önüne Yavuz kruvazörü saat 16:59'da, Demirhisar, Sultanhisar ve Muavenet muhripleri ise saat 17:05'te demirledi. ${ }^{81}$

İstanbul'a doğru yaklaşmakta olan Amerikan gemilerini açık denizde karşılamak ve onlara refakat etmek üzere, Dolmabahçe Sarayı önünde demirli olan Demirhisar, Sultanhisar ve Muavenet muhripleri 4 Nisan günü öğleden sonra hareket hazırlıklarına başladı. Hazırlıklarını tamamlayan muhripler saat 16:45'te Dolmabahçe Sarayı önünden demir aldı. Saat 20:56'da Ereğli Feneri, saat 21:55'de Fener Adası Feneri bordalanarak 4 Nisan günü saat 04:40'ta Çanakkale Boğazından çıkıldı. Seyre devam eden muhripler, Sakız Adası önünde Amerikan gemilerini beklemeye başladı. Saat 14:10'da Missouri zırhlısı, Providence kruvazörü ve Power torpido muhribi göründü. Demirhisar, Sultanhisar ve Muavenet muhripleri saat 14:32'de Missouri zırhlısını, saat 14:33'te Providence kruvazörü ve saat 14:34'te Power torpido muhribini selamladı. Ardından saat 14:45'te Türk muhripleri Amerikan gemilerinin iskele bordasında ${ }^{82}$ mevki aldı ve gemiler topluca İstanbul'a hareket etti. Saat 19:54'te Çanakkale

\footnotetext{
${ }_{77}$ Cumhuriyet, 21 Mart 1946, s.1,3; Cumhuriyet, 23 Mart 1946, s.3.

78 Son Posta, 29 Mart 1946, s.1,3; Ulus, 29 Mart 1946, s.3; Vakit, 04 Nisan 1946, s.2; Ulus, 04 Nisan 1946, s.1,4; Cumhuriyet, 29 Mart 1946, s.1,3; Akşam, 04 Nisan 1946, s.1. Hazırlanan programla misafirler için vapur ve otobüs tahsis edilmesi, Tekel idaresi tarafından "Missouri" adlı bir sigara hazırlanması, özel dizayn kibrit üretilmesi, Kadıköy'den Beşiktaş'a evlerin ve dükkanların aynı renkte boyatılması, tiyatro ve sinemalarda yer tahsisi yapılması düşünüldü. Bu program süreç içerisinde bazı tadilatlara da uğradı. Ayrıntılı bilgi için bkz., Ertan Ünal, "Missouri İstanbul'da", Popüler Tarih Dergisi, Say1 20, Nisan 2002, s.57; Cumhuriyet, 02 Nisan 1946, s.1,3; Akşam, 04 Nisan 1946, s.2.

${ }^{79}$ Cumhuriyet, 31 Mart 1946, s.1,3.

${ }^{80}$ Cumhuriyet, 01 Nisan 1946, s.1; Evening Star, 1 Nisan 1946, s.1; Evening Star, 4 Nisan 1946, s.4.

${ }^{81}$ LDGAM., Gjb., Yavuz Kruvazörü Gemi Jurnali (YKGJ.), Kytn.: 35471, T.: 2 Nisan 1946; LDGAM., Gjb., Demirhisar Muhribi Gemi Jurnali (DMGJ.), Kytn.: 16411, T.: 2 Nisan 1946; LDGAM., Gjb., Zafer Muhribi Gemi Jurnali, Kytn.: 25491, T.: 2 Nisan 1946.

82 İskele Borda: Bir gemi teknesinin su üstünde görünen dış yüzeyine borda adı verilir. İskele ise geminin sol tarafına verilen isimdir. İskele borda denildiğinde gemilerin su üstünde kalan sol taraflarındaki kısımları anlaşılır. Bkz., Seri, age, s.76, 261.
} 
Boğazı'na ulaşan gemiler, 5 Nisan günü saat 01:17'de Hora (Hoşköy) Fenerini bordalayarak, saat 06:00'da Yeşilköy önüne gelerek demirledi. ${ }^{83}$

$\mathrm{Bu}$ sırada Tophane'deki Deniz Askeri Nakliye Komutanlığı önünden saat 06:00'da mihmandarlar ile irtibat subaylar ${ }^{84}$ ve gazetecileri alarak hareket eden Acar motoru, Yeşilköy açıklarında bekleyen Amerikan gemilerine saat 07:00'da bu kişileri ulaştırdı. Missouri zırhlısına sancak taraftan ${ }^{85}$ yanaşan Acar motoru, subaylarla gazetecileri zırhlıya bıraktı. Saat 07:30'da Oramiral Hewitt, gelen misafirlere hitaben bir konuşma yaptı. Gazeteciler Başkan Truman'ın şahsi temsilcisi Mr. Weddell tarafından kabul edildi. Bu sıralarda gemiler Yeşilköy'den hareket etmişti. Missouri zırlısı saat 08:15'te Selimiye Kışlası'nın önüne gelince 21 pare top atışıyla şehri selamladı. Bu selama Selimiye Kışlası'ndan atılan 21 pare top atışıyla karşılık verildi. Gemiler Dolmabahçe önüne yaklaşınca Yavuz kruvazörü, Missouri zırhlısının Amerika'nın Türkiye Büyükelçisi Münir Ertegün'ün naaşını taşıması sebebiyle bayrağını yarıya indirdi. Ardından Amerikan gemileri Yavuz kruvazörü hizasına gelince Missouri zırhlısı bandosu İstiklal Marşı'nı çalmaya başladı. Marş bitince Yavuz kruvazöründeki bando da Amerikan Milli Marşı'nı çaldı. Misafir gemiler saat 09:00'da Dolmabahçe önüne demirledi. ${ }^{86}$

Gemiler demirledikten sonra Donanma Komutanı ve İstanbul Deniz Komutanı adına birer vizite subayı Missouri zırhlısına giderek Oramiral Hewitt'i ziyaret etti. Bu ziyaretlerin hemen ardından Amerikalı subaylar tarafından, bu ziyarete karşl11k olarak iadei ziyaretler yapıldı $1{ }^{87}$

Sonrasında Büyükelçi Münir Ertegün'ün naaşı, saat 10:00'da bir motorla Dolmabahçe rıhtımına çıkarıldı. ${ }^{88}$ Naaş, Amerikan ve Türk deniz subayları arasındaki top arabasına kondu. Saat 10:30'da Oramiral Hewitt, Başkan Truman'ın şahsi temsilcisi Mr. Weddell ve Tümamiral James rihtıma çıktı. Onları tören için orada olan Vali/Belediye Başkanı Lütfi Kırdar ve aralarında Donanma Komutanı Kormiral Mehmet Ali Ülgen' in ${ }^{89}$ de olduğu kalabalık bir zevat karşıladı. Bandoların sırayla çaldığı cenaze marşı eşliğinde Beşiktaş yoluyla Sinanpaşa camisi önüne gelindi. Burada Türk ve Amerikan kıtalarının yaptığı geçit resmi sonrası merasim sona erdi. Büyükelçi Münir Ertegün'ün naaşı defnedilmek üzere Asri mezarlığa götürüldü. ${ }^{90}$

Öğleden sonra saat 13:05'te, Yavuz kruvazöründen 17 pare top atışıla Oramiral Hewitt selamlandı ve Missouri'den aynı adet top atışıla karşılık verildi. Saat 14:00'da Donanma Komutanı Koramiral Mehmet Ali Ülgen, yanında Harp Filosu Komutanı, çeşitli filotilla komutanları, Deniz Kurmay Başkanı Amiral Sadık Altıncan, Yavuz kruvazörü komutanı ve

${ }^{83}$ LDGAM., Gjb., DMGJ., Kytn.: 16411, T.: 3, 4 ve 5 Nisan 1946; Akşam, 05 Nisan 1946, s.1; Son Posta, 05 Nisan 1946, s.1,3; Tanin, 05 Nisan 1946, s.1; Vakit, 05 Nisan 1946, s.2; Cumhuriyet, 04 Nisan 1946, s.1; Ulus, 05 Nisan 1946, s.1, 4.

84 Dz.Kur.Bnb. Şemsi Bargut ve Dz.Kur.Bnb. Selim Albatros Missouri zırhlısında görevlendirilen irtibat subaylarındandı. Bkz., Şemsi Bargut, “Anılar”, Deniz Kuvvetleri Dergisi, S.577, Ankara 2000, s.8.

${ }^{85}$ Sancak Taraf: Bir geminin güvertesinde yüz pruvaya (baş taraf) dönüldüğünde geminin sağ tarafında kalan yönüdür. Bkz., Seri, age, s.432.

${ }^{86}$ LDGAM., Gjb., DMGJ., Kytn.: 16411, T.: 5 Nisan 1946; Cumhuriyet, 06 Nisan 1946, s.2; Vakit, 06 Nisan 1946, s.1,4; Ulus, 06 Nisan 1946, s.1; Tanin, 06 Nisan 1946, s.1; Türk Deniz Kuvvetleri Tarihçesi 1935-1950, Cilt II, Dosya III, Lalahan Deniz Genel Arşiv Müdürlüğü Yayını, Ankara, a.467; Bülent Işın, Cumhuriyet Bahriyesi Kronolojisi 1923 'ten 2005 'e, Deniz Basımevi, İstanbul 2006, s.52; Nurcan Bal- Figen Atabey, Türk Deniz Kuvvetleri, Bin Yılın Güncesinden Seçmeler, Deniz Kuvvetleri Komutanlığı Yayını, İstanbul 2009, s.103.

${ }^{87}$ Ulus, 06 Nisan 1946, s.1,4; Cumhuriyet, 06 Nisan 1946, s.2.

${ }^{88}$ Cumhuriyet, 06 Nisan 1946, s.1.

${ }^{89}$ Kormiral Mehmet Ali Ülgen: 1886 İstanbul doğumludur. 30 Ağustos 1945 tarihinde Harp Filosu Komutanlığından Donanma Komutanlığına atanmış, 1 Temmuz 1949 tarihinde Türkiye Cumhuriyeti Devleti'nin ilk Deniz Kuvvetleri Komutanı olmuştur. Bkz., LDGAM., Mehmet Ali Ülgen Şahsi Dosyası.

${ }^{90}$ Vakit, 06 Nisan 1946, s.1,4; Tanin, 06 Nisan 1946, s.1,2; Ulus, 06 Nisan 1946, s.1,4; Cumhuriyet, 06 Nisan 1946, s.3; Akşam, 06 Nisan 1946, s.1. 
Cumhuriyet Devri Diplomat Naaşlarının Nakillerinde Savaş Gemilerinin Kullanılması Örnekleri...

muhtelif komutanlarla Missouri zırhlısını ziyaret etti. Saat 14:45'te ise Oramiral Hewitt ve maiyeti Yavuz kruvazörüne gelerek iadei ziyarette bulundu. ${ }^{91}$

Oramiral Hewitt saat 15:30'da karaya çıktı ve Vali/Belediye Başkanı Lütfi Kırdar'ı ziyaret etti. Saat 16:30 ise Vali/Belediye Başkanı Lütfi Kırdar Missouri zırhlısına giderek iadei ziyarette bulundu.

Oramiral Hewitt, Başkan Truman'ın şahsi temsilcisi Mr. Weddell, 12 yüksek rütbeli subay ve 8 gazeteci, yanlarında Amerikan Büyükelçisi Mr. Wilson olduğu halde akşamki Ankara ekspresine bağlanan özel vagonlarla Ankara'ya hareket etti. Kendilerini Vali/Belediye Başkanı Lütfi Kurdar ve aralarında Donanma Komutanı Koramiral Mehmet Ali Ülgen'in de bulunduğu komutanlar yolcu etti. Ayrıca saat 20:30'da misafir denizciler şerefine Harp Filosu Komutanı tarafindan bir akşam yemeği verildi. ${ }^{92}$

Amerikalı denizciler, 6 Nisan'da saat 10:00'da Taksim Cumhuriyet Anıtına törenle çelenk koydu. Saat 09:15'te Dolmabahçe'ye çıkan silahendaz takımı, bando eşliğinde Gazhane ve Gümüşsuyu yoluyla Taksim meydanına çıktı. Doğruca daha önce Taksim Cumhuriyet Anıtı önünde bandosuyla birlikte mevki alan Türk silahendaz takımı yanına ilerledi. Türk ve Amerikan milli marşlarının çalınması ardından çelenk koyulmasıyla tören sona erdi. ${ }^{93}$

Cumhurbaşkanı ismet İnönü, 6 Nisan 1946 tarihinde saat 16:00’da Çankaya Köşkü’nde Amerikan Başkanı Truman'ın şahsi temsilcisi Mr. Weddell, Oramiral Hewitt, Tümamiral James, Tuğamiral Shelley, Tuğamiral Mc Candlish, Missouri zırhlısı komutanı Albay Hillen Kootter, Providence kruvazörü komutanı Albay Ryan ve Power torpido muhribi komutanı Yarbay Steinbeck'i kabul etti. Amerikan Büyükelçisi Mr. Wilson, Amerikalı misafirleri Cumhurbaşkanına takdim etti. Bu kabul esnasında Dış İşleri Bakanı Hasan Saka da hazır bulundu. ${ }^{94}$ Heyet, Mustafa Kemal Atatürk'ün naaşının geçici olarak tutulduğu Etnoğrafya Müzesi’ni de ziyaret etti. Ayrıca heyet sırasıyla; Genelkurmay Başkanı, Milli Savunma Bakanı, Dış İşleri Bakanı, Başbakan ve Meclis Başkanını ziyaret edip akşam ekspresiyle İstanbul'a döndü. ${ }^{95}$

İstanbul'daki karşılama 7 Nisan sabahı oldu. Haydarpaşa garında yapılan karşılamada Vali/Belediye Başkanı Lütfi Kırdar ve aralarında Donanma Komutanı Koramiral Mehmet Ali Ülgen'in de bulunduğu komutanlar yer ald1. ${ }^{96}$ Amerikan heyeti, saat 17:00'da Amerikan elçiliğinde bir kokteyl parti verdi. Bu partide ev sahibi sıfatıyla Amerikan Başkanı Truman'ın şahsi temsilcisi Mr. Weddell, Oramiral Hewitt, Tümamiral James, Tuğamiral Shelley, Tuğamiral Mc. Candlish, Missouri zırhlısı komutanı Albay Hillen Kootter, Providence kruvazörü komutanı Albay Ryan ve Power torpido muhribi komutanı Yarbay Steinbeck ile geniş bir askeri heyet yer aldı. Konuk sıfatıyla ise Vali/Belediye Başkanı Lütfi Kırdar ve aralarında Donanma Komutanı Koramiral Mehmet Ali Ülgen'in de bulunduğu geniş bir davetli

\footnotetext{
${ }^{91}$ Cumhuriyet, 06 Nisan 1946, s.2; Tanin, 06 Nisan 1946, s.6; Ulus, 06 Nisan 1946, s.1,4.

${ }^{92}$ Ulus, 06 Nisan 1946, s.1,4; Cumhuriyet, 06 Nisan 1946, s.2; Tanin, 06 Nisan 1946, s.6; Vakit, 07 Nisan 1946, s.4; Akşam, 06 Nisan 1946, s.2.

${ }^{93}$ Vakit, 07 Nisan 1946, s.1,3; Ulus, 07 Nisan 1946, s.1,4; Cumhuriyet, 07 Nisan 1946, s.1,3; Tanin, 07 Nisan 1946, s.1; Akşam, 07 Nisan 1946, s.1.

${ }_{94}$ Tanin, 07 Nisan 1946, s.1; Cumhuriyet, 07 Nisan 1946, s.1; Ulus, 07 Nisan 1946, s.1,4; Vakit, 07 Nisan 1946, s.1,4.

95 Akşam, 07 Nisan 1946, s.1; Cumhuriyet, 07 Nisan 1946, s.3; Vakit, 07 Nisan 1946, s.4; Ulus, 07 Nisan 1946, s.1,4: Tanin, 07 Nisan 1946, s.2.

${ }^{96}$ Ulus, 08 Nisan 1946, s.1,4; Cumhuriyet, 08 Nisan 1946, s.1; Tanin, 08 Nisan 1946, s.1.
} 
grubu bulundu. Akşam ise Dolmabahçe sarayında, aynı gruba Vali/Belediye Başkanı Lütfi Kırdar tarafından bir balo düzenlendi. ${ }^{97}$

Oramiral Hewitt, 8 Nisan'da Missouri zırhlısında bir öğle yemeği verdi. Yemeğe, Vali/Belediye Başkanı Lütfi Kırdar ile aralarında Donanma Komutanı Koramiral Mehmet Ali Ülgen'in de bulunduğu komutanlar ve vilayetin önde gelen isimleri katıldı. Yemeği, saat 16:00'da verilen kokteyl takip etti. Bu faaliyetler sırasında ziyaretçi üç gemiye özel olarak hazırlanmış üç gümüş plaka ile üç halı hediye edildi. Etkinliklerin sona ermesinin ardından Donanma Komutanı Koramiral Mehmet Ali Ülgen akşam saat 20:00'da Amerikalı denizciler şerefine Perapalas otelinde akşam yemeği ve suare tertipledi. ${ }^{98}$

Amerikan gemilerinin ziyareti süresince Amerikan denizcileri ve Türk sporcuları arasında spor müsabakaları düzenlemek için özel bir komisyon oluşturuldu. Komisyon Beden Terbiyesi Umum Müdürü Vildan Aşır Savaşır ${ }^{99}$ başkanlığında çalışmalar yaptı. ${ }^{100} 25$ Mart günü yapılan ilk toplantıda Amerikalılar adına Mr. Yang'da hazır bulundu. Bu toplantıda önceden hazırlanan taslak program ${ }^{101}$ üzerinde çalışıldd. ${ }^{102}$ Sonrasında netleştirilen programa göre ilk müsabaka, 5 Nisan akşamı Taksim gazinosunda yapılacak boks maçıydı. 6 ve 7 Nisan'da Eminönü ve Kadıköy Halkevlerinde basketbol maçları yapılacaktı. Ayrıca 6 Nisan'da Amerikalılar, Şeref Stadyumu'nda ${ }^{103}$ beyzbol oynayacak, 7 Nisan'da ise Taksim Dağcılık Klübünde tenis maçları yapilacakt1. ${ }^{104}$

Yapılması planlanan müsabakalardan, Taksim gazinosunda yapılan boks karşılaşmalarında Türk sporcular, Amerikalı sporculara karşı büyük bir üstünlük kurdu. Amerikalı denizcilerle yapılan karşılaşmalarda Türk boksörler, 11 maçtan 5'inde galip gelirken, 3 maçı berabere bitirdi, 3 maçtan da mağlup ayrıldı. ${ }^{105}$ Gösteri niteliğinde yapılması planlanan bir diğer karşılaşma ise beyzbol oynanmasıydı. 6 Nisan'da Şeref Stadyumu'nda oynanması planlanan beyzbol maçları Fenerbahçe stadında yapıldı. Missouri zırhlısı ve Power torpido muhribi denizcilerinden oluşan takımların yaptığı maçı, Missouri zırhlısı takımı 8-3 kazandı. Aynı gün yapılan diğer karşılaşmalar ise basketbol maçlarıydı. Yapılacak karşılaşmalar için Amerikalı denizciler Missouri ve Providence gemilerinden birer basketbol takımı çıkardı. İlk maç Kadıköy Halkevinde Missouri ile Beykoz takımları arasında oldu. Maçı 38-29 Beykoz takımı

\footnotetext{
${ }^{97}$ Cumhuriyet, 08 Nisan 1946, s.3; Ulus, 08 Nisan 1946, s.1,4; Türk Deniz Kuvvetleri Tarihçesi 1935-1950, age, a.467.

98 Akşam, 09 Nisan 1946, s.1; Tanin, 09 Nisan 1946, s.2; Cumhuriyet, 09 Nisan 1946, s.1; Ulus, 09 Nisan 1946, s.1,4.

99 1903-1986 yılları arasında yaşamıs Türk sporcu ve yöneticisidir. Stockholm Yüksek Beden Terbiyesi Enstitüsü'nü bitirdi. Avrupa milletlerinin beden eğitimi konusu üzerine takip ettikleri metotları öğrenmek ve memlekete dönüşlerinde beden eğitimi öğretmeni yetiştirmek amacıyla, Millî Eğitim Bakanlığı tarafindan 1925 yılında İsveç Stockholm'deki Kraliyet Yüksek Beden Eğitimi Enstitüsü'ne gönderildi. 1939 yılından sonra devlet kademesinde çalışmaya başladı. 1945 - 1950 arası Beden Terbiyesi Umum Müdürlüğü görevini yürüttü. Savaşır, ayrıca 1943 1950 yılları arasında Türkiye Milli Olimpiyat Komitesi başkanlığı görevini de sürdürdü. Ayrıntılı bilgi için bkz., http://sgm.gsb.gov.tr/Sayfalar/219/110/vildan-asir-savasir.aspx. (E.T. 16.04.2020)

${ }^{100}$ Cumhuriyet, 27 Mart 1946, s.3.

${ }^{101}$ Cumhuriyet, 24 Mart 1946, s.3

102 Cumhuriyet, 26 Mart 1946, s.3.

${ }^{103}$ Stadyumun bulunduğu alan Çırağan Sarayı'nın bahçesiydi. 19 Ocak 1910 günü çıkan büyük bir yangın sonucu harap olan Çırağan Sarayı'nın bahçesi, Beşiktaş JK yöneticilerinden Ahmed Şerafeddin Bey'in (Şeref Bey) 1932 tarihinde başlayan girişimleriyle stadyuma dönüştü. Şeref Bey yakalandığı kanser hastalığından hayatını kaybedince, stadyuma onun adı verildi. Beşiktaş, 1947'de İnönü Stadyumu açılana kadar lig maçlarını burada oynandı. Şeref Stadyumu'nun 1986 tarihinde yıkılmasından sonra stadın yerine Çırağan-Kempinski Oteli inşa edildi. Ayrıntılı bilgi için bkz., https://tr.wikipedia.org/wiki/\%C5\%Şeref_Bey (E.T. 16.04.2020)

${ }_{104}$ Cumhuriyet, 02 Nisan 1946, s.3; Akșam, 02 Nisan 1946, s.2.

105 Tanin, 09 Nisan 1946, s.2; Cumhuriyet, 09 Nisan 1946, s.1,3; Cumhuriyet, 13 Nisan 1946, s.2; Akşam, 09 Nisan 1946, s.2.
} 
kazandı. İkinci maç ise Eminönü Halkevinde Galatasaray ile Providence basketbol takımları arasında yapıldı. Maçı 52-40 Galatasaray kazandı. ${ }^{106}$ Amerikalı denizcilerin tenisçileriyle, İstanbul tenis takımı arasında 7 Nisan'da Taksim Dağcılık Klübü kortlarında yapılan tenis karşılaşmalarını ise kalabalık bir izleyici kitlesi takip etti. Maçlar dostluk havası içinde geçti. ${ }^{107}$

Missouri zırhlıs1, Providence kruvazörü ve Power torpido muhribi İstanbul'da bulunduğu süre içerisinde halkın ziyaretine açıldı ve büyük ilgi gördü. ${ }^{108}$ Gemileri gezmek isteyenler için önceden hazırlanmış davetiyeleri temin etmek gerekmekteydi. ${ }^{109}$ Misafir bahriyeliler de İstanbul'a büyük ilgi gösterdi. ${ }^{10}$ Özellikle müzeler, tarihi yerler, Boğaziçi ve Kapalıçarşı gezildi. Bu gezilerde kendilerine tahsis edilen vapur ve otobüsler kullanıldı. ${ }^{111}$

Türk Donanması için Missouri zırhlısı, bir savaş gemisinin teknolojik olarak gelebildiği en son noktada yer alması sebebiyle çok önemliydi. Özellikle geminin silah sistemleri, telsiz ve radar teçhizatı, sualtı cihazları, seyir teçhizat ve tertibatı, makine ve kazan sistemleri hakkında bilgi sahibi olunması gerekmekteydi. Bu bilgilerin sadece teknik konularla sınırlı kalmaması, gemideki vardiya usulleri, erlerin iaşe şekilleri ile yedirilen gıdalar ve gemideki giyim kuşam biçimleriyle tüm yaşam koşullarının gözden geçirilmesi düşünüldü. Bahsedilen bu konuları gemi üzerinde incelemek için Deniz Müsteşarlığı dörder subaydan oluşan iki çalışma grubu oluşturdu. ${ }^{112}$ Birinci grup 4 Nisan 1946 tarihinde Ankara'dan hareket edip 5 Nisan günü gemideki incelemelerini yapacaktı. İkinci grup ise 6 Nisan günü Ankara'dan hareket ederek 7 Nisan günü gemiyi inceleyecekti. ${ }^{113}$ Burada yapılan incelemelerde elde edilen bilgiler, modern ve çağdaş bir donanmaya sahip olmaya çalışan Türkiye için hayati derecede önemliydi. ${ }^{114}$

\subsection{Amerikan Gemilerinin Açık Denizde Uğurlanması}

Münir Ertegün'ün naaşını getiren ve Türkiye ziyaretini tamamlayan Missouri zırhlısı, Providence kruvazörü ve Power torpido muhribi 9 Nisan 1946 sabahı ayrılış hazırlıklarına başladı. Saat 09:30'da Providence kruvazörü, saat 09:34'te Power torpido muhribi ve saat

${ }^{106}$ Ulus, 07 Nisan 1946, s.4; Cumhuriyet, 07 Nisan 1946, s.1,4; Tanin, 07 Nisan 1946, s.6; Akşam, 07 Nisan 1946 , s.2.

${ }^{107}$ Cumhuriyet, 06 Nisan 1946, s.2; Cumhuriyet, 07 Nisan 1946, s.4; Cumhuriyet, 08 Nisan 1946, s.2.

108 Son Posta, 31 Mart 1946, s.1,3; Son Posta, 07 Nisan 1946, s.2; Vakit, 06 Nisan 1946, s.4; Cumhuriyet, 07 Nisan 1946, s.2; Cumhuriyet, 10 Nisan 1946, s.2.

${ }^{109}$ Davetiyeler hakkında ayrıntılı bilgi için bkz., Vakit, 05 Nisan 1946, s.2-4; Cumhuriyet, 05 Nisan 1946, s.3.

110 Amerikalı bahriyeliler kulaktan dolma bilgiler ile Türkiye hakkında oldukça olumsuz düşüncelere sahipti. Hatta bazı Amerikalılar şalvarlı, kamalı ve bıçaklı Türklerin nerelerde adam soyup öldürdüklerini gösteren bir İstanbul haritasıyla dolaşıyordu. Missouri zırhlısını gezen Türk subayları bu haritalardan birini alıp Donanma Komutanı Kormiral Mehmet Ali Ülgen'e getirdi. Donanma Komutanı bu haritayı Oramiral Hewitt'e gösterdiğinde Amerikalı amiral gülerek "Siz memleketinizi tanıtamıyorsanız biz ne yapabiliriz?" demiştir. Bkz., Afif Büyüktuğrul, Cumhuriyet Donanmasının Kuruluşu Strasında 60 Yll Hizmet (1918-1977), Cilt II, Deniz Basımevi Müdürlüğü, İstanbul 2005, s.578.

${ }^{111}$ Tanin, 06 Nisan 1946, s.6; Vakit, 07 Nisan 1946, s.3; Tanin, 07 Nisan 1946, s.2; Cumhuriyet, 07 Nisan 1946, s.4; Ulus, 08 Nisan 1946, s.4; Tanin, 08 Nisan 1946, s.2. Bu ziyaretler sırasında çeşitli kazalar da yaşandı. Bu kazalardan biri, 7 Nisan 1946 Pazar günü meydana geldi. Kiraladıkları bir sandalla Missouri zırhlısını görmek isteyen 3 arkadaş, Unkapanı'ndan Dolmabahçe önlerine geldi. Dolmabahçe'yi kaplayan kesif sis yüzünden ağır ağır ilerleyen sandala, karşı istikametten gelen kırmızı bir motor çarptı ve sandal parçalandı. Kaza, Providence kruvazörüyle Demirhisar muhribinden görüldü ve indirilen filikalarla 3 kişi kurtarıldı. Bkz., Cumhuriyet, 09 Nisan 1946, s.2. Bunun yanında Türk ve Amerikan bahriyelileri arasında ufak tefek sürtüşmeler de görüldü. Örnek bir olay için bkz., Kazım Erbil, Bahriyede Gördüklerim Duyduklarım, Kastaş Yayınevi, İstanbul 2007, s.114-115.

${ }^{112}$ LDGAM., Ktn.:1946-90, Gmn.:80, Bn.:1, T.:3 Nisan 1946.

${ }^{113}$ LDGAM., Ktn.:1946-90, Gmn.:80, Bn.:2, T.:3 Nisan 1946.

${ }^{114}$ Oluşturulan grupların incelemeleri neticesinde hazırladıkları raporlara, arşivlerde yapılan araştırmalar neticesinde ulaşılamamıştır. 
10:00'da Missouri zırhlısı Dolmabahçe Sarayı önünden hareket etti. Bu gemilere refakat etmek ile görevli Muavenet, Demirhisar ve Sultanhisar muhripleri de demir aldı. ${ }^{115}$

Gemiler Yavuz kruvazörünün önünden geçerken güvertedeki bando tarafından Amerikan Milli Marşı çalındı. Muavenet, Demirhisar ve Sultanhisar muhripleri eşiliğinde İstanbul'dan ayrılan gemiler, Çanakkale istikametine doğru yoluna devam etti. Bu sırada içi İstanbullularla dolu Denizyollarına ait 10 adet vapur da Sirkeci'den Yeşilköy'e kadar kafileye eşlik etti. ${ }^{116}$

Toplu olarak seyre devam eden gemiler saat 17:25'te Gelibolu Fenerini, saat 18:50'de Kilitbahir'i bordalayarak Çanakkale Boğazından çıktı. Türk muhripleri Ege Denizinde saat 22:20'ye kadar Amerikan gemilerine eşlik etti ve bu saatte geri dönüşe geçildi. Muhripler 10 Nisan günü saat 00:08'de Zincirbozan'1 bordalayarak, saat 06:30'da Maltepe önüne demirledi. Amerikan gemileri ise 10 Nisan 1946 tarihinde Pire limanına ulaştı. ${ }^{117}$

Amerikan gemilerinin Türkiye'den ayrılmasından sonra, Türkiye'de görevli Amerika Deniz Ataşesi Albay Webb Trammell, hem Genelkurmay Başkanlığına hem de Genelkurmay Başkanlığı Deniz Müşaviri Tuğamiral Sadık Altıncan'a ${ }^{118}$ birer teşekkür mektubu yolladı. Bu mektuplarda, Amiral Hewitt ve komutası altındaki gemilerin İstanbul'a gerçekleştirdikleri ziyaret sırasında gösterilen büyük dostluk ve misafirperverlik için nezaket ve teşekkür mesajı iletildi. Gönderilen mesajda özellikle başta Albay Zeki Bayat ${ }^{119}$ olmak üzere irtibat subaylarına ilgi ve alakaları için ayrıca teşekkür edildiği bildirildi. ${ }^{120}$ İlaveten; Genelkurmay Başkanı Orgeneral Kazım Orbay'da, Genelkurmay Başkanlığınca düzenlenen programın uygulanmasında gösterilen titizlik ve elde edilen başarıdan dolayı, ilgili tüm personele teşekkür etti. $^{121}$

\section{Sonuç}

Tarih kaleme alınırken, tarihi yazanlar, öznel birikimlerinden sıyrılıp tamamen objektif olamaz. Çünkü yaşamı boyunca okuduklarından, duyduklarından ve öğrendiklerinden edindikleri, tarihi yazan kişinin ister istemez objektif olmasını engeller. Özellikle yıllarca devlet hizmetinde bulunmuş, çeşitli kademelerde görevler üstlenmiş ve yaptıklarıyla bir siyasi kimlik kazanmış kişiler hakkında yazmak ise bilimselliği korumak adına başka zorluklar barındırır. Hakkında yazı yazılacak kişilerin diplomat kimliği taşıması ve görev yaptıkları ülkelerde görev başında vefat etmeleri konusu da yoruma açık bir alan oluşturduğu için içinde daha farklı zorluklar taşır. Bu konunun değerlendirme sürecinde ise; hayatını görev başında kaybeden diplomatın kim olduğu, olayın hangi iki ülke arasında hangi tarihte gerçekleştiği ve o dönemki konjonktürel bakış açısının ne olduğu etkilidir ve meselenin zorluk seviyesini artırır.

\footnotetext{
${ }^{115}$ LDGAM., Gjb., YKGJ., Kytn.: 35471, T.: 9 Nisan 1946; LDGAM., Gjb., DMGJ., Kytn.: 16411, T.: 9 Nisan 1946; Evening Star, 10 Nisan 1946, s.5; Evening Star, 15 Nisan 1946, s.3.

${ }^{116}$ Akşam, 09 Nisan 1946, s.1; Son Posta, 10 Nisan 1946, s.1,7; Vakit, 10 Nisan 1946, s.1,4; Ulus, 10 Nisan 1946, s.1,4; Cumhuriyet, 10 Nisan 1946, s.1,3; Tanin, 10 Nisan 1946, s.1,2.

${ }^{117}$ LDGAM., Gjb., DMGJ., Kytn.: 16411, T.: 10 Nisan 1946; Cumhuriyet, 11 Nisan 1946, s.1.

118 Tuğamiral Mehmet Sadık Altıncan 12 Mayıs 1944 tarihinde Albay rütbesiyle Genelkurmay Başkanlığı Deniz Müşaviri görevine atandı. 30 Ağustos 1945 tarihinde Tuğamiral oldu. Genelkurmay Başkanlığı Deniz Müşaviri görevini 13 Ağustos 1946 tarihinde atandığı Harp Filosu Komutan Vekilliği görevine kadar sürdürdü. Bkz., LDGAM., Mehmet Sadık Altıncan Şahsi Dosyası.

119 Albay Zeki Taftil Bayat 16 Mayıs 1944 tarihinde Albay rütbesiyle İstanbul Deniz Komutanlığı Muavinliğine görevine atandı. 30 Ağustos 1947 tarihinde Tuğamiral oldu. İstanbul Deniz Komutanlığı Muavinliği görevini 16 Ağustos 1946 tarihinde atandığı II.Muhrip Filotillas1 Komodorluğu görevine kadar sürdürdü. Bkz., LDGAM., Zeki Taftil Bayat Şahsi Dosyası.

${ }^{120}$ LDGAM., Ktn.:1946-8, Gmn.:79, Bn.:2, T.:11 Nisan 1946.

${ }^{121}$ LDGAM., Ktn.:1946-8, Gmn.:79, Bn.:1, T.:18 Nisan 1946.
} 
Cumhuriyet Devri Diplomat Naaşlarının Nakillerinde Savaş Gemilerinin Kullanılması Örnekleri...

$\mathrm{Bu}$ açılardan bakılarak, Cumhuriyet Döneminde görev başında hayatını kaybeden ve ülkesine, görev yaptığı ülkenin bir savaş gemisiyle nakledilen diplomatlar konusu ele alındığında, meseleye kaynaklık etmesi bakımından Osmanlı Hariciye Nazırı Keçecizade Mehmet Fuad Paşa'nın vefatı ve naaşının nakledilmesi karşımıza çıkar.

Fuad Paşa'nın Fransa'daki vefatı ve sonrasında yaşananlar değerlendirildiğinde mesele; Tanzimat Fermanının yayınlanmasından sonra başlayan ve Kırım Savaşı ile yükselen Osmanlı Fransa yakınlaşmasında, Fransa'nın rekabet halinde olduğu İngiltere'ye karşı yapılmış bir hamlesi şeklinde ele alınabilir. Nitekim Fransa, bu olaya verdiği tarihi önemi vurgulamak adına cenazenin nakli için Le Renard isimli modern teknolojiye sahip son sistem bir savaş gemisi seçti. Böylece Fransa, jeopolitik ve jeostratejik konumu sebebiyle vazgeçemediği Osmanlı Devleti'ne jest yaparak, diplomatik yakınlık seviyesini artırmayı hedefledi.

Benzer şekilde, Cumhuriyet Döneminde bu sefer Rusya ve Amerika'da yaşanan Türk diplomat vefatlarında aynı yöntemin izlendiği görüldü. Zaman ve mekan değişse de devletler bu durumu, hem karşı devlete saygı göstermek hem de kendi çıkarları için kullanmaktan çekinmedi.

Yine bu açılardan bakıldığında Sovyet Rusya Büyükelçisi Vasıf Çınar'ın 2 Haziran 1935 tarihinde Moskova'da hayatını kaybetmesi de Türk Sovyet ilişkilerinin geleceği açısından imkan sağlayacak bir sembol olarak değerlendirildi. Vasıf Çınar'ın görev periyodu; Türkiye Sovyet Rusya münasebetleri bakımından büyük problemlerin görülmediği, hatta temeli çok eskilere dayanan düşmanlıkların dostluğa dönüştüğü bir süreç oldu. Vasıf Çınar'ın vefatı, Sovyetler Birliği tarafından Türkiye ile olan ilişkinin güçlendirilmesi için bir firsata çevrilmeye çalışıldı ve bu nedenle Vasıf Çınar'ın naaşının İstanbul'a bir Rus savaş gemisiyle gönderilmesine karar verildi. Bu uygulama ile Türkiye'ye verilen değer gösterilirken, ayak sesleri duyulan II.Dünya Savaşı öncesinde Türkiye'nin Rusya'ya yaklaşması amaçlandı. Rusya bu hamle neticesinde, Amerika başta olmak üzere tüm Dünyaya açık bir mesaj vermek gayretindeydi.

Aynı şekilde, 1946 yılında Münir Ertegün'ün naaşının Amerikan Donanmasının en modern gemilerinden biri olan Missouri zırhlısıyla Türkiye'ye gönderilmesinde de diplomatik nezaketin ötesinde bir şeyler aramak gerekir. Her ne kadar Münir Ertegün II.Dünya Savaşı'nın temelleri atılırken ve savaş sırasında Türkiye ile Amerika arasındaki siyasi, kültürel, askeri ve ekonomik ilişkilerin en üst düzeyde yürütülmesini sağladıysa da yapılan bu hareket, uygulamanın altındaki farklı düşüncelerin yattı̆̆ 1 gerçeğini gizlemeye yetmez. Çünkü hangi diyalektik yöntemle analiz edilirse edilsin Türkiye, bu olaydan sonra Amerika'nın Balkanlar, Ortadoğu ve Kafkasya bölgelerindeki en önemli müttefiklerinden biri haline gelmiştir. İlaveten Türkiye, kısa bir süre sonra NATO içerisine girerek de Sovyetler Birliği karşısında esaslı bir Amerikan dostuna dönüşmüştür.

Diplomat naaşlarının savaş gemileriyle ülkesine gönderilmesi uygulamasında amaçlanan şey, karşı devlete olan saygıyı gösterirken aynı zamanda bu olayı kendi çıkarları için kullanma düşüncesinden kaynaklanmaktaydı. Bu sebeple 1869 tarihinde Fransa Osmanlı Devleti'ne, 1935 yılında Rusya ve 1946 yılında da Amerika, Türkiye Cumhuriyeti Devletine aynı kaygılarla yaklaştı.

Tüm bu bilgiler 1şığında kısaca ifade etmek gerekirse; II.Dünya Savaş1 öncesinde Rusya, Türkiye'ye yakınlaşmak için Sovyet Rusya'da vefat eden Sovyet Rusya Büyükelçisi Vasıf Çınar'ın naaşının bir Rus savaş gemisiyle nakledilmesini kullanırken, aynı şekilde bu sefer II.Dünya Savaşı sonrası Amerika, Türkiye'ye yakınlaşmak için Amerika'da vefat eden Amerika Birleşik Devletleri Büyükelçisi Münir Ertegün'ün naaşının bir Amerikan savaş 
gemisiyle Türkiye’ye nakledilmesini kullandı. Böylelikle bu iki büyükelçi, ölümlerinden sonra dahi, ülkelerine hizmet etmeye devam etmiş oldu.

\section{Kaynakça}

\section{A- Arşivler, Gemi Jurnalleri}

Cumhurbaşkanlığı Devlet Arşivleri Başkanlığı

Donanma Komutanlığı Deniz Tarihi Arşiv Kısmı Fotoğraf Arşivi

Lalahan Deniz Genel Arşiv Müdürlüğü

1935 Y1lı Kocatepe Muhribi Gemi Jurnali

1946 Y11 Demirhisar Muhribi Gemi Jurnali

1946 Yı1ı Yavuz Kruvazörü Gemi Jurnali

1946 Yılı Zafer Muhribi Gemi Jurnali

\section{B-Süreli Yayınlar (Gazeteler):}

\begin{tabular}{c|l} 
UH & $\begin{array}{l}\text { Akşam } \\
\text { Cumhuriyet }\end{array}$ \\
\hline HISTORY & Evening Star \\
\hline $\mathbf{9 4 9}$ & Hakimiyet - i Milliye \\
& Kurun \\
Volume 12 \\
Issue 3 \\
June \\
2020 & Son Posta \\
& Tanin \\
& The Sphere \\
& The Wilmington Morning Star \\
& Ulus \\
& Vakit \\
& C- Kitap, Makale, Tez
\end{tabular}

“Amerikan Filosunun İstanbul'u Ziyareti”, Deniz Kuvvetleri Dergisi, C.58, S.377, Ankara 1946, s.136-137.

AHMET LÜTFÜ, Vak'a-Nüvis Ahmed Lütfi Efendi Tarihi, Hzl. Münir Aktepe, C.XII, Türk Tarih Kurumu Yayınları, Ankara 1989.

AKALIN, Cüneyt, "Missouri'nin Ziyaretinin Tarihsel Anlamı”, Yakın Dönem Türkiye Araştırmaları Dergisi, Y.II/2003, S.III, s.1-13.

AKALIN, Cüneyt, Soğuk Savaş ABD ve Türkiye - 1 Olaylar - Belgeler (1945 -1952), Kaynak Yayınlar1, İstanbul 2003.

ARI, Tayyar, Uluslararası İlişkiler ve Dış Politika, İstanbul 1997.

ARIKAN, Zeki, "Vasıf Çınar'ın Yaşamı ve Hizmetlerine Toplu Bir Bakış”, Vasıf Çınar Yaşamı ve Hizmetleri Anma Toplantısl, Türk Ĕ̈itim Derneği VII. Anma Toplantısı, (27 Ekim 1999 Ankara), Türk Eğitim Derneği Yayınları, Ankara 1999, s.49-55. 
Cumhuriyet Devri Diplomat Naaşlarının Nakillerinde Savaş Gemilerinin Kullanılması Örnekleri...

ARMAOĞLU, Fahir, "1920 Yllında Millî Mücadele ve Sovyet Rusya”, VII. Türk Tarih Kongresi Bildirileri, Türk Tarih Kurumu Yayınları, Cilt II, Ankara 1973, s.893-900.

ARMAOĞLU, Fahir, 20. Yüzyıl Siyasi Tarihi 1914-1995, Cilt I-II, Alkım Yayınevi, İstanbul 2005.

Atatürk'ün Türkiye Büyük Millet Meclisi Açış Konuşmaları, TBMM Basımevi, Ankara1987.

BAL, Nurcan - ATABEY, Figen, Türk Deniz Kuvvetleri, Bin Yllın Güncesinden Seçmeler, Deniz Kuvvetleri Komutanlığı Yayını, İstanbul 2009.

BARAN, Tülay Alim, Vasıf Çınar ve İzmir'e Doğru Gazetesi Yazıları, İstanbul 2001.

BARGUT, Şemsi, “Anılar”, Deniz Kuvvetleri Dergisi, S.577, Ankara 2000, s.8-9.

BAŞ, Ersan, Türk Tarihinde Yavuz Zırhlısının Rolü, Deniz Basımevi Müdürlüğü, İstanbul 2008.

BÜYÜKTUĞRUL, Afif, Cumhuriyet Donanmasinın Kuruluşu Sirasinda 60 Yll Hizmet (19181977), Cilt II, Deniz Basımevi Müdürlügüü, İstanbul 2005.

Cumhuriyet Ansiklopedisi 1923-2000, C.II (1941-1960), Yap1 Kredi Yayınları, İstanbul 2003.

DEVELLİĞLU, Ferit, Osmanlıca-Türkçe Ansiklopedik Lûgat, Aydın Kitabevi, Ankara 1998.

E.Dz.Kur.Alb. Celal Denizalp’in Anıları, Donanma Komutanlığı Deniz Tarihi Arşivi Müdürlüğü Yayını, Kocaeli 2002.

ERBİL, Kazım, Bahriyede Gördüklerim Duyduklarım, Kastaş Yayınevi, İstanbul 2007.

ERTEM, Barış, "İkinci Dünya Savaşı Sırasında Türkiye Sovyetler Birliği İlişkileri ve Türkiye'nin Amerika Birleşik Devletleri ile Yakınlaşmasına Etkileri”, Turkish Studies Dergisi, Volume 8/7, Ankara 2013, s.157-183.

EYİCE, Semavi, “Tarihi Mezarlardan Notlar IV-Keçecizade Fuad Paşa'nın Mezarı”, İstanbul Üniversitesi Edebiyat Fakültesi Tarih Enstitüsü Dergisi, Edebiyat Fakültesi Matbaas1, Ağustos 1973-1974, s.304-313.

EYMA, Xavier,"Les Obseques de Fuad-Pacha”, L'Illustration-Journal Universel, LIII, S.1357, 27 Şubat 1869, s.Kapak ve 130.

GÜLER, Yavuz, "II. Dünya Harbi Sonrası Türkiye-Amerikan İlişkileri (1945-1950)”, Ahi Evran Üniversitesi Kırşehir Eğitim Fakültesi Dergisi, C.V, S.II, Kırşehir 2004, s. 209-224.

GÜMÜŞSOY, Emine Atılgan, Keçecizâde Mehmed Fuad Paşa (1815-1869), (Gazi Üniversitesi Sosyal Bilimler Enstitüsü, Basılmamış Doktora Tezi), Ankara 2006.

IŞIN, Bülent, Cumhuriyet Bahriyesi Kronolojisi 1923 'ten 2005'e, Deniz Basımevi, İstanbul 2006.

İNAL, İbnülemin Mahmud Kemal, Son Sadrazamlar I-V, Milli Eğitim Bakanlığı Devlet Kitapları Basımevi, İstanbul 1969.

İNALCIK, Halil, Kuruluş ve İmparatorluk Sürecinde Osmanlı, Timaş Yayınları, İstanbul 2011.

İNANÇ, Gül, “US Missouri Zırhlısı'nın İstanbul Ziyareti ve Soğuk Savaş Diplomasisinde Türkiye, 1946" Toplumsal Tarih, S.191, İstanbul 2009, s.48,55. 
KARAKAŞ, Nuri, Türk-Amerikan Siyasi Ilişskileri (1939-1952), Atatürk Araştırma Merkezi Yayını, Ankara 2013.

KÖPRÜLÜ, Orhan Fuad, "Fuad Paşa, Keçecizâde (1815-1869)", Türkiye Diyanet Vakfi İslâm Ansiklopedisi, C.XIII, Türkiye Diyanet Vakf1 Yayınları, İstanbul 1996.

KÖSTEM, Orhun, “Ailesinden Biri Gözüyle Vasıf Çınar”, Vasıf Çınar Yaşamı ve Hizmetleri Anma Toplantısı, Türk Eğitim Derneği VII. Anma Toplantısı, (27 Ekim 1999 Ankara), s.41-49.

MÜEZZINNOĞLU, Ersin, “İsmet Paşa'nın 1932 Sovyet Rusya Ziyareti”, Afyon Kocatepe Üniversitesi Sosyal Bilimler Dergisi, Cilt 20, Sayı 2, Eylül 2018, s.249-260.

ORAN, Baskın, Türk Dış Politikası (Kurtuluş Savaşından Bugüne, Olgular, Belgeler, Yorumlar), Cilt I 1919-1980, İletişim Yayınları, İstanbul 2002.

ÖZTUNA, Yılmaz, Keçecizade Fuat Paşa, Kültür ve Turizm Bakanlığı Yayınları, İstanbul 1988.

ÖZTÜRK, Fatma, Mehmet Münir Ertegün'ün Hayatı ve Türk Yakınçă̆g'ndaki Yeri, (Uşak Üniversitesi Sosyal Bilimler Enstitüsü, Yayımlanmamış Doktora Tezi), Uşak 2016.

SAKAOĞLU, Necdet, "Vasıf Çınar ve Tevhid-i Tedrisat Kanunu", Vasıf Çınar Yaşamı ve Hizmetleri Anma Toplantısl, Türk Ĕgitim Derneği VII. Anma Toplantısl, (27 Ekim 1999 Ankara), s.17-32.

SERİ, Burhanettin, Denizcilik Ansiklopedisi, Deniz Basımevi, İstanbul 2009.

Volume 12

Issue 3

June

2020

ŞİMŞiR, Bilal N., Bizim Diplomatlar, Bilgi Yayınevi, Ankara 1996.

T.Fred Jane's, All The World Fighting Ships 1940, Francis E., McMurtie, London, England 1940.

T.Fred Jane's, All The World Fighting Ships 1944-1945, Francis E., McMurtie, London, England 1945.

T.Fred Jane's, All The World Fighting Ships 1946-1947, Francis E., McMurtie, London, England 1947.

T.Fred Jane's, All The World Fighting Ships 1949-1950, Francis E., McMurtie, London, England 1950.

TEKELİ, İlhan - İLKİN, Selim, Dış Siyaseti ve Askeri Stratejileriyle İkinci Dünya Savaşı Türkiyesi, Cilt I, İletişim Yayınları, İstanbul 2014.

TUNÇAY, Mete, Türkiye'de Sol Akımlar (1925-1936), Cilt II, BDS Yayınları, İstanbul 1992.

TURAN, Şerafettin, Mustafa Kemal Atatürk, Kendine Özgü Bir Yaşam ve Kişilik, Bilgi Yayınevi, Ankara 2008.

TUTEL, Eser, Seyr-i Sefain Öncesi ve Sonrası, İletişim Yayınevi, İstanbul 2000.

Türk Deniz Kuvvetleri Tarihçesi 1923-1935, Lalahan Deniz Genel Arşiv Müdürlügü̈ Yayını, Cilt Nu.,I., Ankara.

Türk Deniz Kuvvetleri Tarihçesi 1935-1950, Cilt II, Dosya III, Lalahan Deniz Genel Arşiv Müdürlüğü Yayını, Ankara.

UÇAROL, Rifat, Siyasi Tarih 1789-1994, Filiz Kitabevi, İstanbul 1995. 
Cumhuriyet Devri Diplomat Naaşlarının Nakillerinde Savaş Gemilerinin Kullanılması Örnekleri...

UĞURAL, Ragıp, "Vasıf Çınar ve İzmir'e Doğru”, Vasıf Çınar Yaşamı ve Hizmetleri Anma Toplantısı, Türk Eğitim Derneği VII. Anma Toplantısı, (27 Ekim 1999 Ankara), s.3441.

ÜNAL, Ertan, "Missouri İstanbul'da”, Popüler Tarih Dergisi, Say1 20, Nisan 2002, s. 56- 62.

YILMAZ, Tuğçe Gözde, Tarihsel - Tiyatral Kişilik İlişkisinin Jeanne D’arc Konulu Oyunlara Yansımasl, (Dokuz Eylül Üniversitesi Güzel Sanatlar Enstitüsü Sahne Sanatları Anabilim Dalı, Yayınlanmamış Yüksek Lisans Tezi), İzmir 2010.

\section{D- İnternet Sayfası}

http://washington.emb.mfa.gov.tr/Mission/MissionChiefHistory (E.T. 05.04.2020)

http://sgm.gsb.gov.tr/Sayfalar/219/110/vildan-asir-savasir.aspx. (E.T. 16.04.2020)

http://www.turkcerrahi.com/tip-sozlugu/periton (E.T. 11.09.2019)

http://www.turkcerrahi.com/tip-sozlugu/periton (E.T. 11.09.2019)

http://moskova.be.mfa.gov.tr/Mission/About (E.T. 11.09.2019)

https://www.sehirhatlari.istanbul/tr/kurumsal (E.T. 11.11.2019)

https://www.wrecksite.eu/wreck.aspx?286303(E.T.08.04.2020)

https://fr.wikipedia.org/wiki/Le_Renard_(aviso) (E.T. 08.04.2020)

https://en.wikipedia.org/wiki/USS_Power_(DD-839) (E.T. 15.04.2020)

https://en.wikipedia.org/wiki/USS_Providence_(CL-82) (E.T. 15.04.2020).

https://tr.wikipedia.org/wiki/\%C5\%Şeref_Bey (E.T. 16.04.2020)

ume 12 


\section{Ekler}

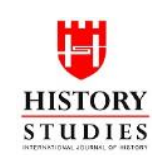

953

Volume 12

Issue 3

June

2020

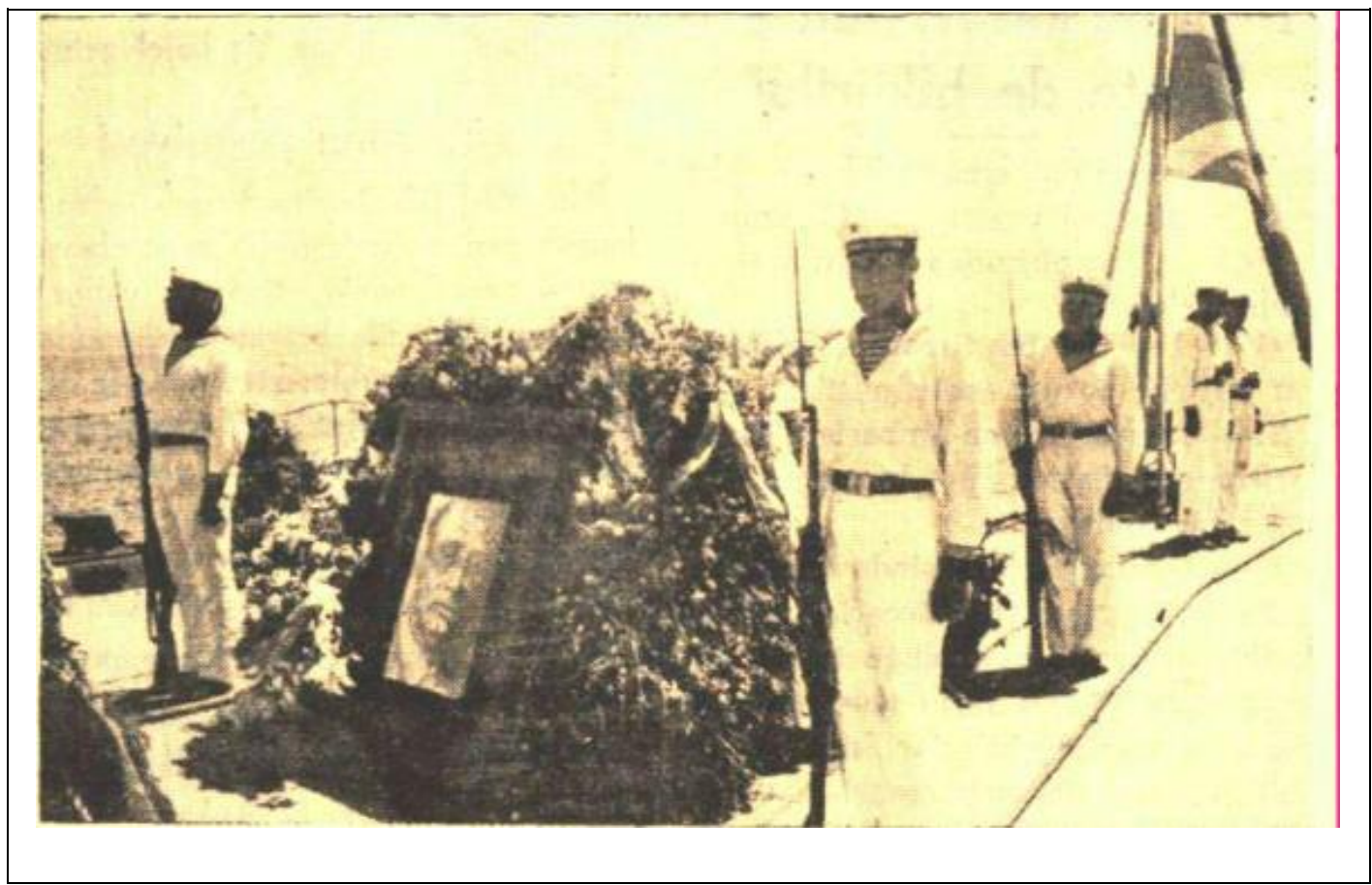

Ek 1: Vasıf Çınar'ın Cenazesi, Rus Kruvazörü Chervonaya Ukraina'nın Güvertesinde Rus Bahriyelilerle. Cumhuriyet Gazetesi, 8 Haziran 1935, s.1.

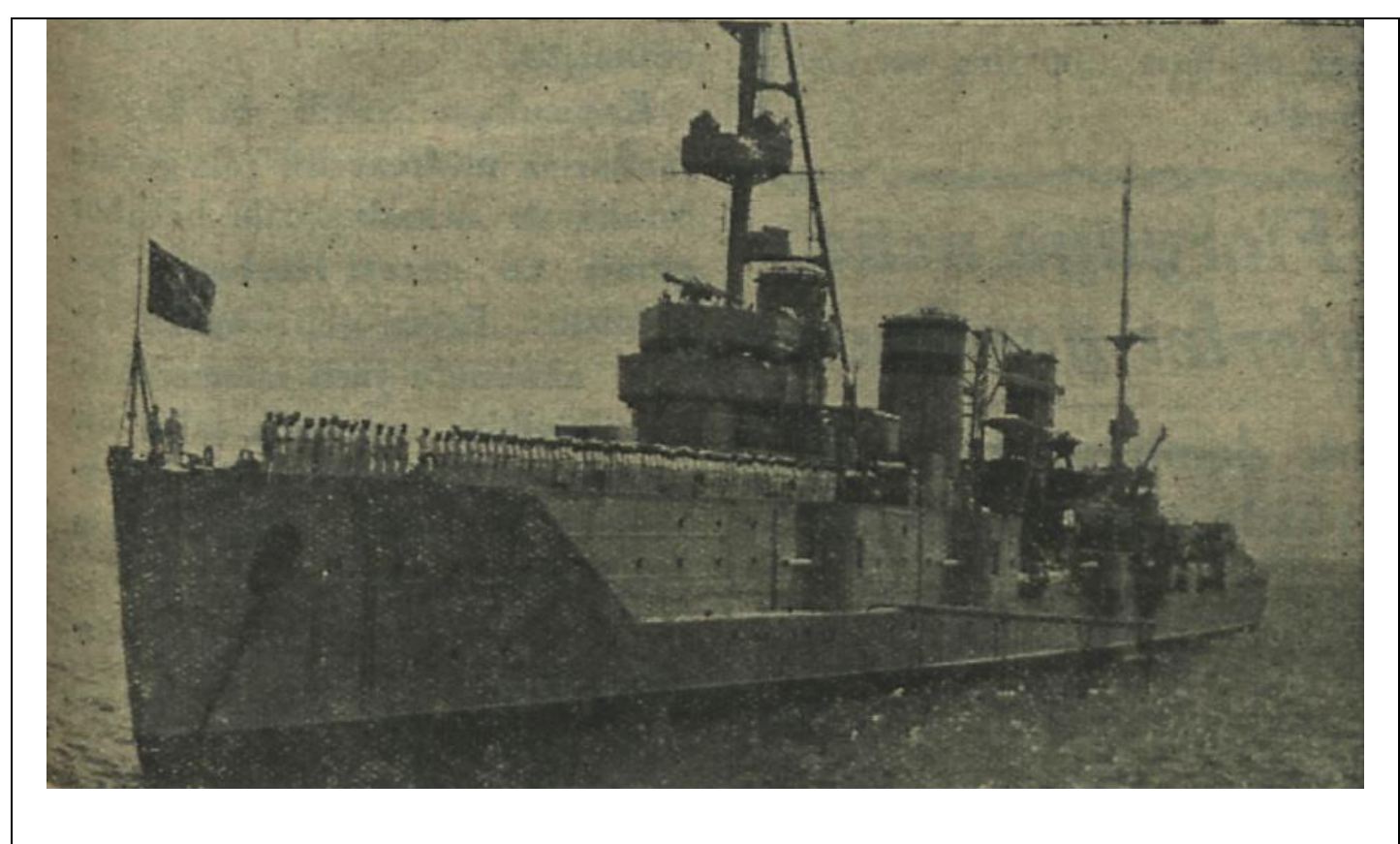

Ek 2: Vasıf Çınar'ın Cenazesini Getiren Rus Kruvazörü Chervonaya Ukraina Haydarpaşa Önlerindeyken. Akşam Gazetesi, 8 Haziran 1935, s.1. 
Cumhuriyet Devri Diplomat Naaşlarının Nakillerinde Savaş Gemilerinin Kullanılması Örnekleri...

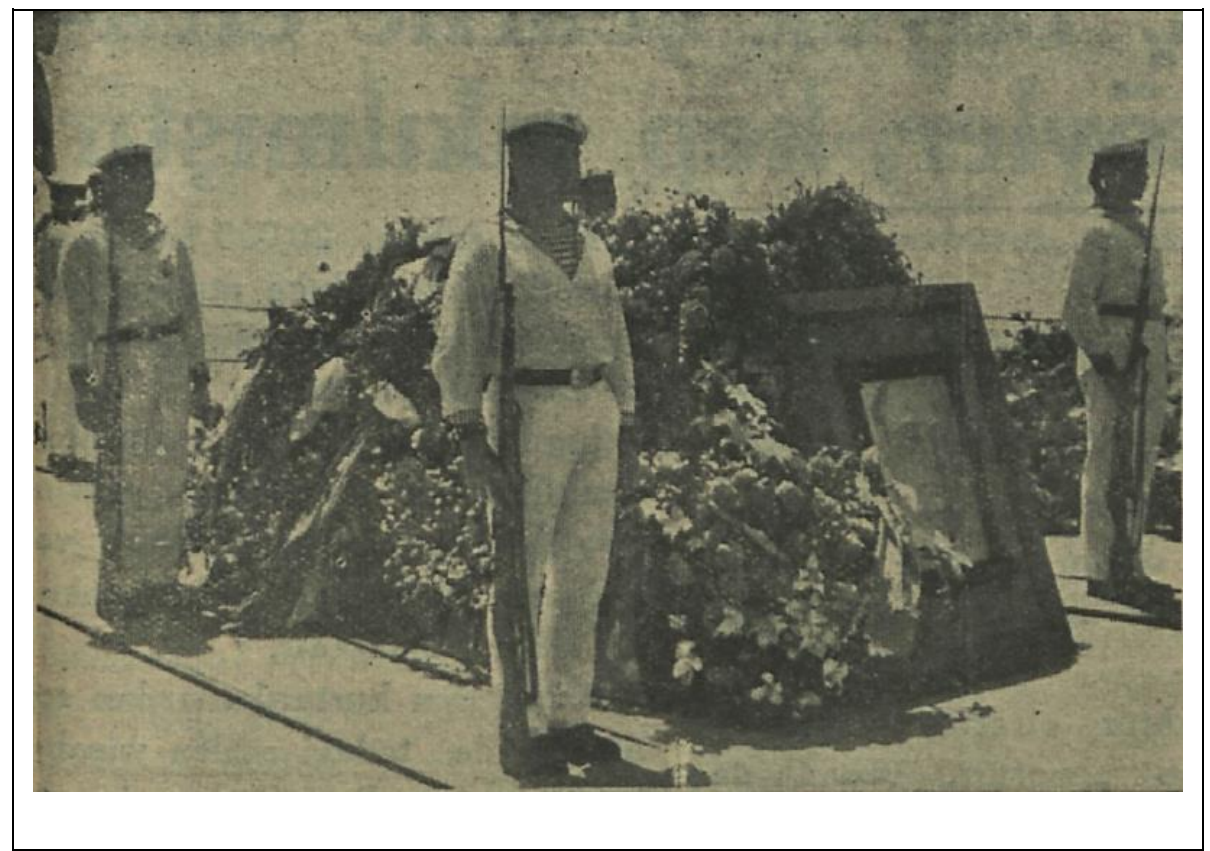

Ek 3: Vasıf Çınar'ın Cenazesi, Rus Kruvazörü Chervonaya Ukraina'nın Güvertesinde Rus Bahriyelilerle. Akşam Gazetesi, 8 Haziran 1935, s.1.

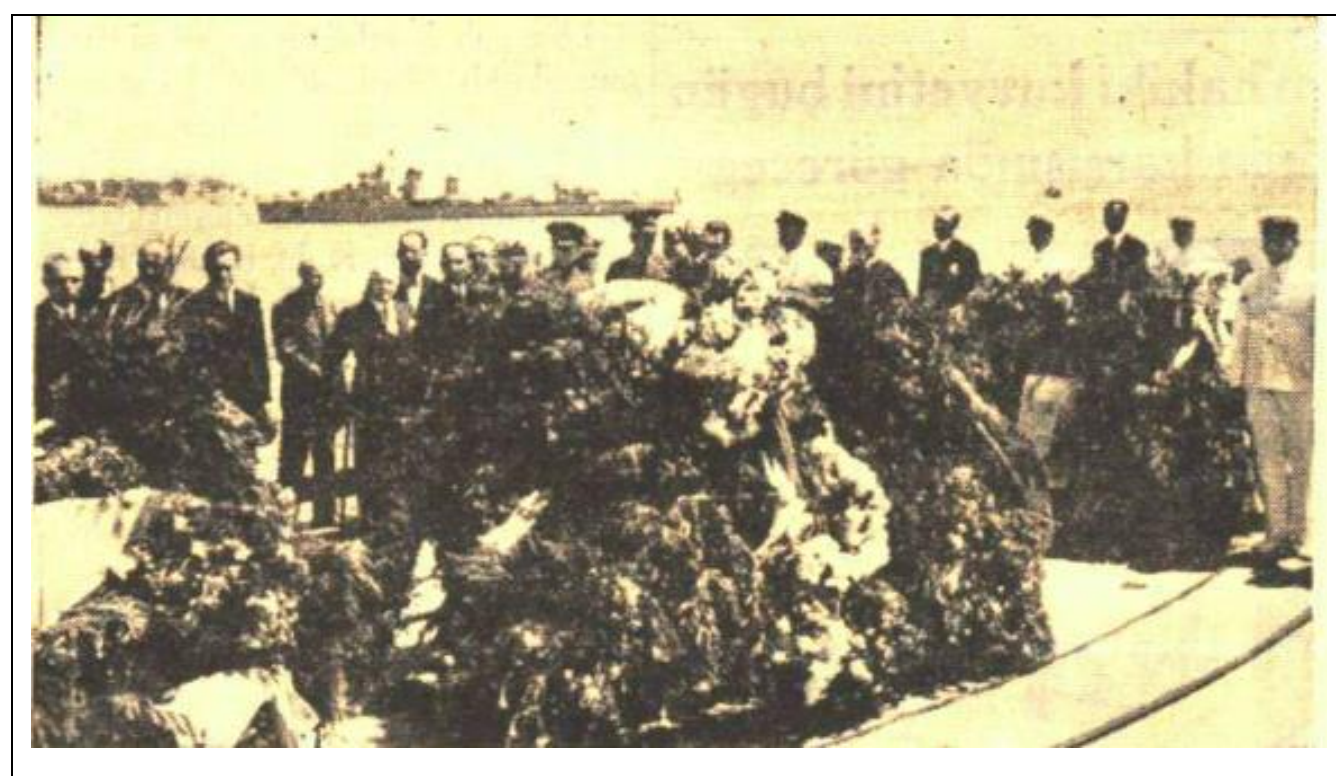

Ek 4: Vasıf Çınar'ın Cenazesi Rus Kruvazörü Chervonaya Ukraina'nın Güvertesindeyken İcra Edilen 3 Dakikalık Saygı Duruşu Sırasında Çekilmiş Fotoğraf. Cumhuriyet Gazetesi, 8 Haziran 1935, s.7. 
y
HISTORY STUDIES

955

Volume 12

Issue 3

June

2020

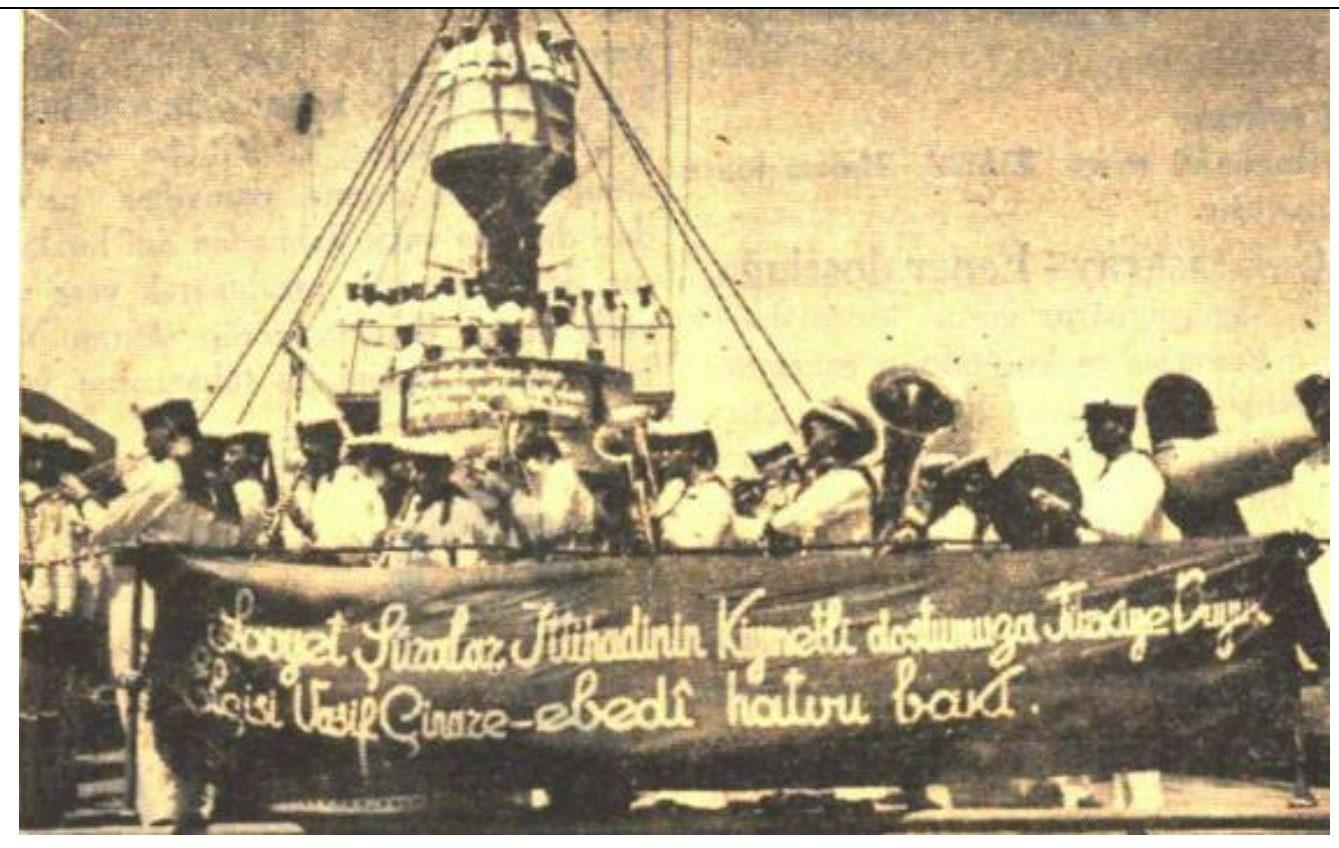

Ek 5: Vasıf Çınar'ın Cenazesi Rus Kruvazörü Chervonaya Ukraina'dan Ayrılırken Çalınan Marş Sırasında Çekilmiş Fotoğraf. Cumhuriyet Gazetesi, 8 Haziran 1935, s.7.

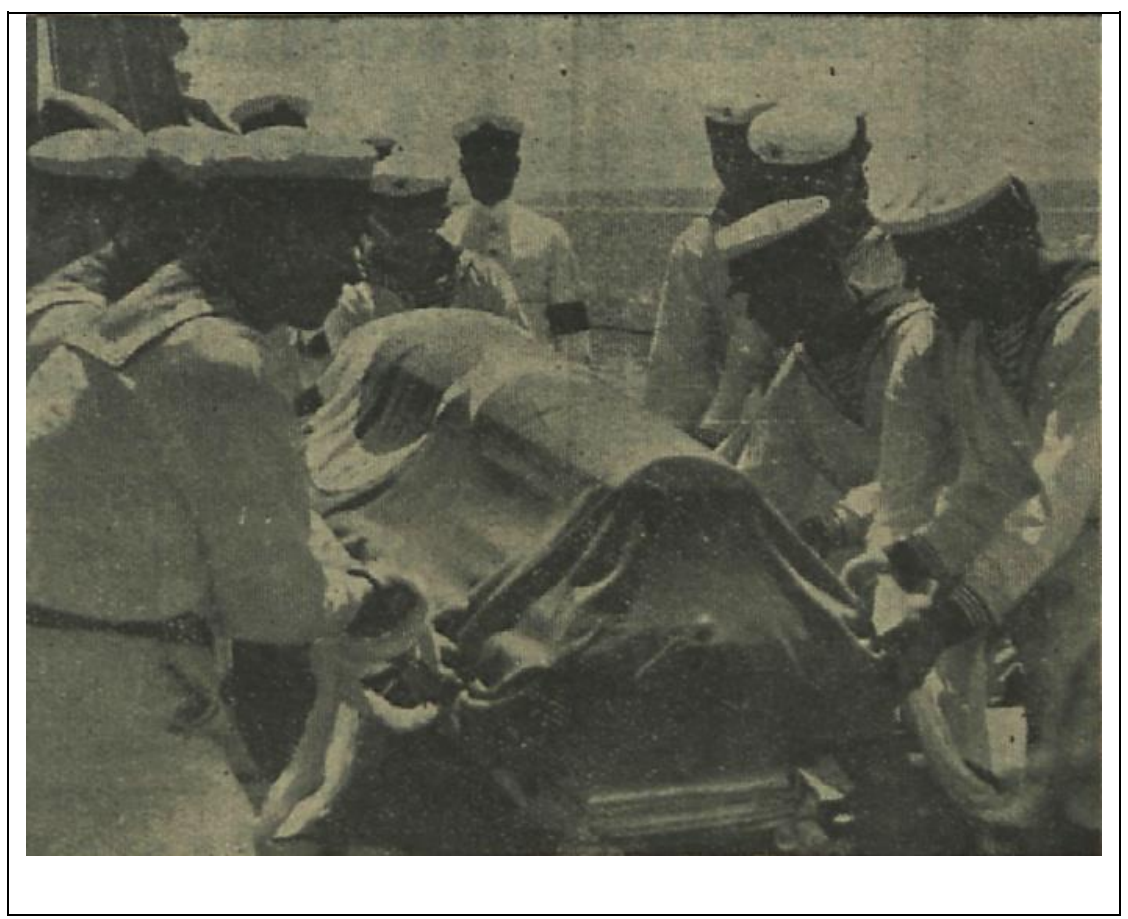

Ek 6: Vasıf Çınar'ın Cenazesi Rus Kruvazörü Chervonaya Ukraina'dan 57 Numaralı Şirketi Hayriye Vapuruna Nakledilirken. Akşam Gazetesi, 8 Haziran 1935, s.1. 
Cumhuriyet Devri Diplomat Naaşlarının Nakillerinde Savaş Gemilerinin Kullanılması Örnekleri...

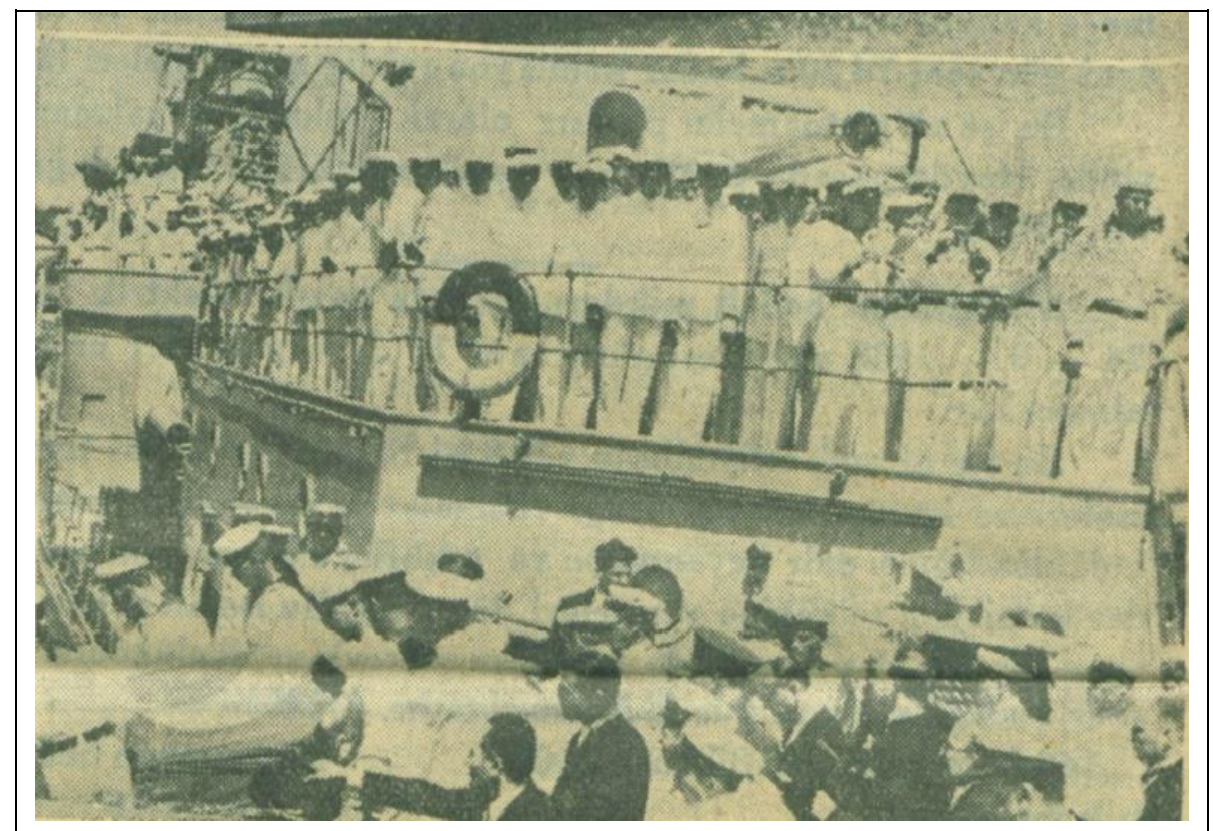

Ek 7: Vasıf Çınar'ın Cenazesi Rus Kruvazörü Chervonaya Ukraina'dan 57 Numaralı Şirketi Hayriye Vapuruna Nakledilirken. Kurun Gazetesi, 8 Haziran 1935, s.16.

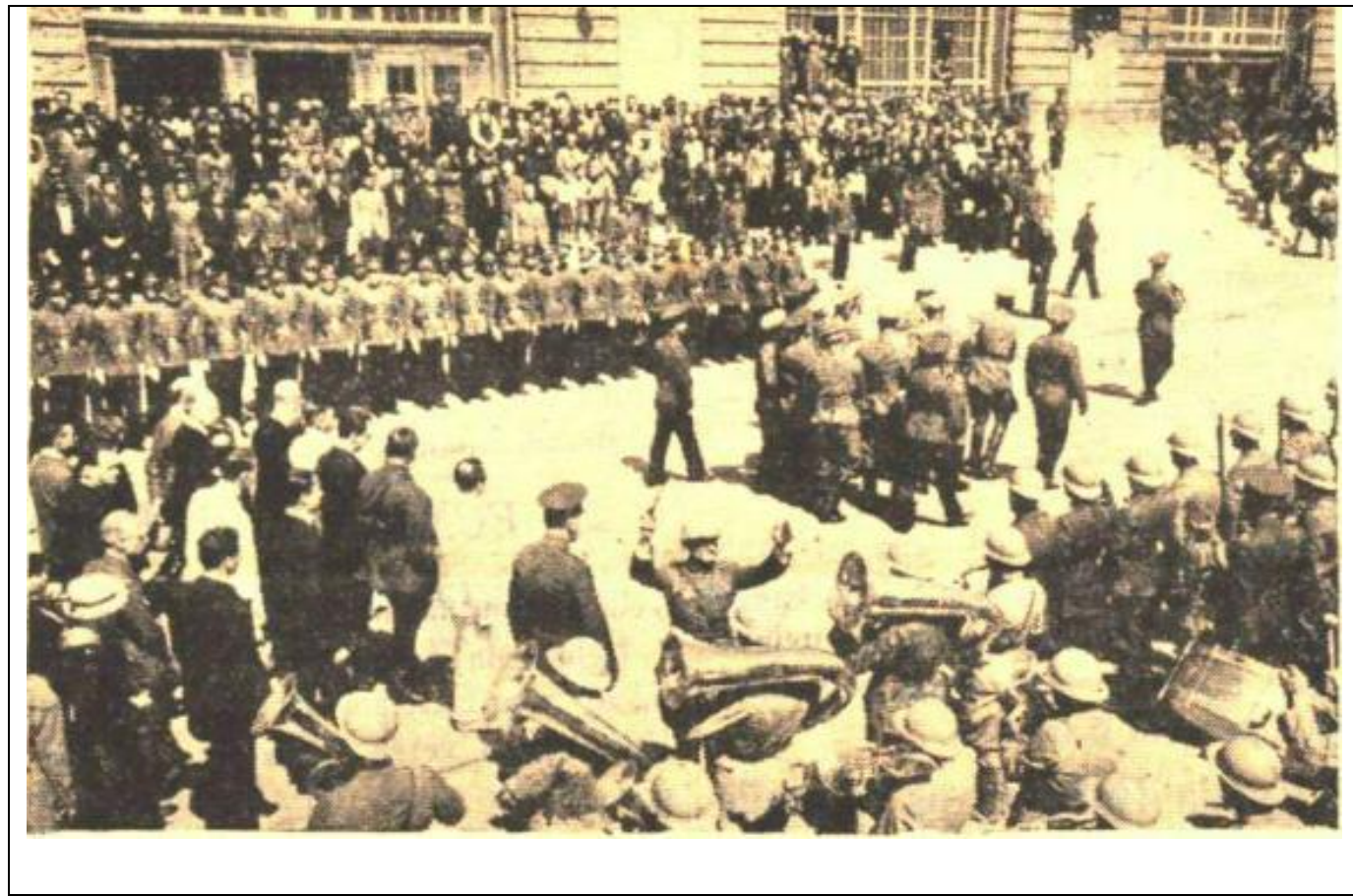

Volume 12

Issue 3

June

2020

Ek 8: Vasıf Çınar'ın Cenazesi Haydarpaşa Garı'na Nakledilirken. Cumhuriyet Gazetesi, 8

Haziran 1935, s.7. 
Ferdi Uyanıker

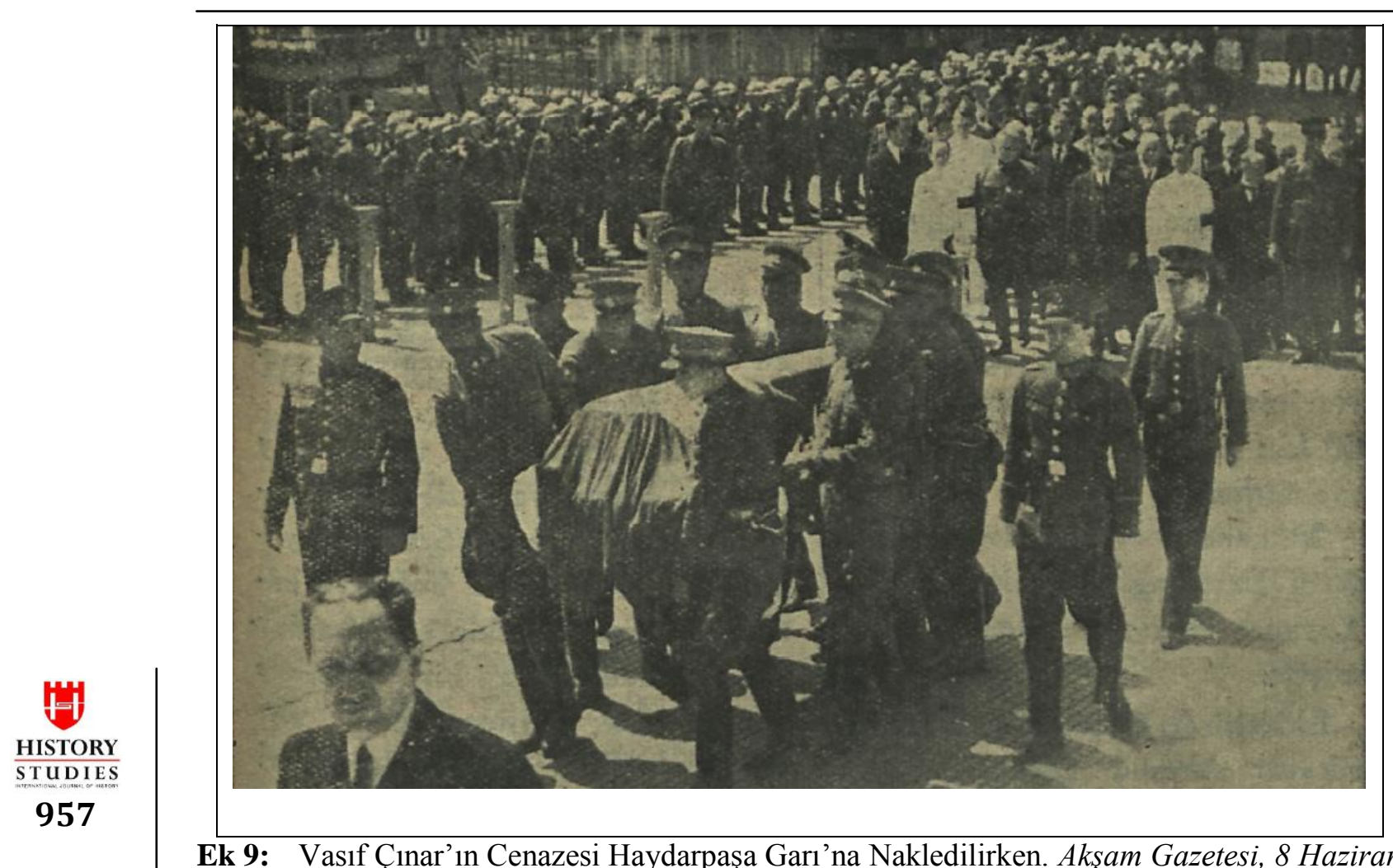

Volume 12

Ek 9: Vasıf Çınar'ın Cenazesi Haydarpaşa Garı'na Nakledilirken. Akşam Gazetesi, 8 Haziran

Issue 3

June 1935, s.1.

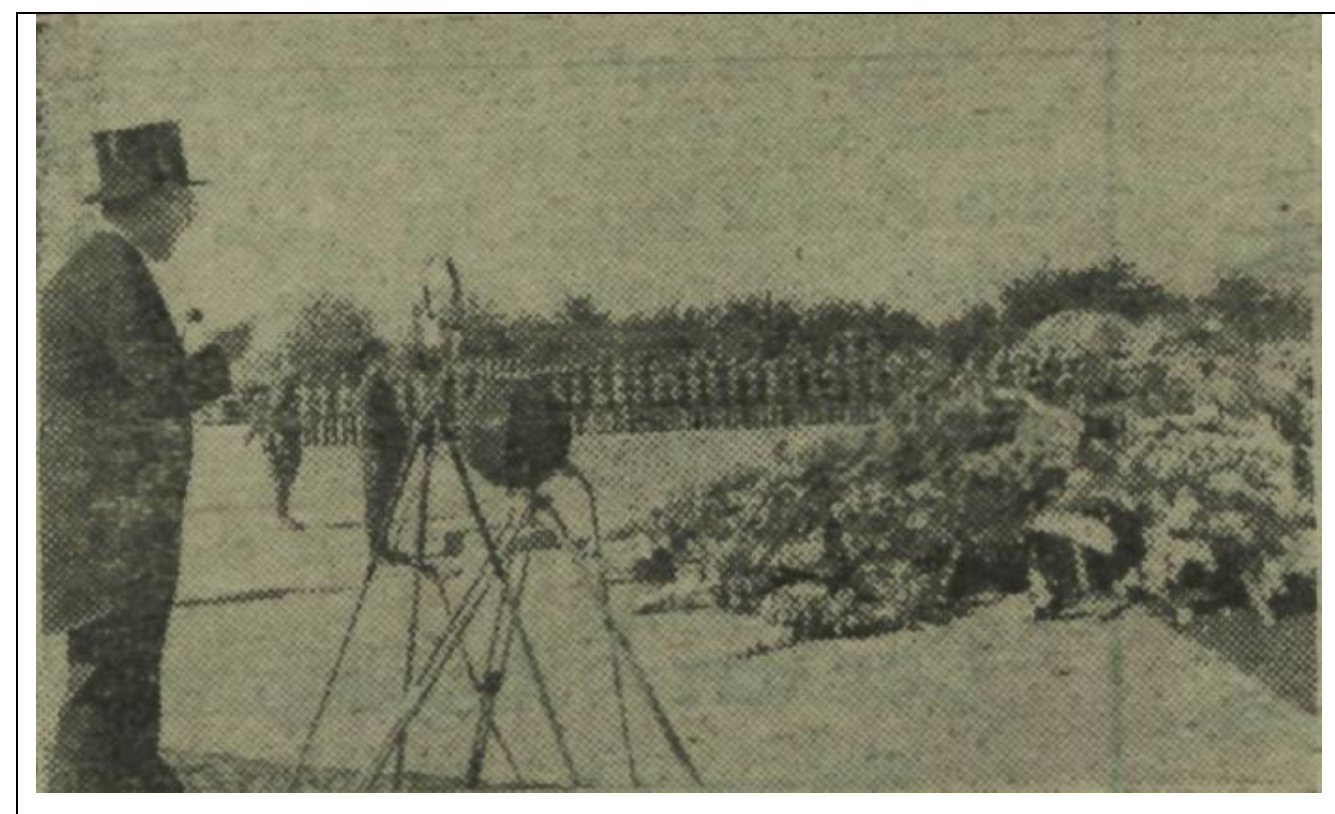

Ek 10: Vasıf Çınar İçin Ankara İstasyon Meydanında Yapılan Törende Dışişleri Bakanı Tevfik Rüştü Aras Konuşma Yaparken. Ulus Gazetesi, 9 Haziran 1935, s.1. 
Cumhuriyet Devri Diplomat Naaşlarının Nakillerinde Savaş Gemilerinin Kullanılması Örnekleri...

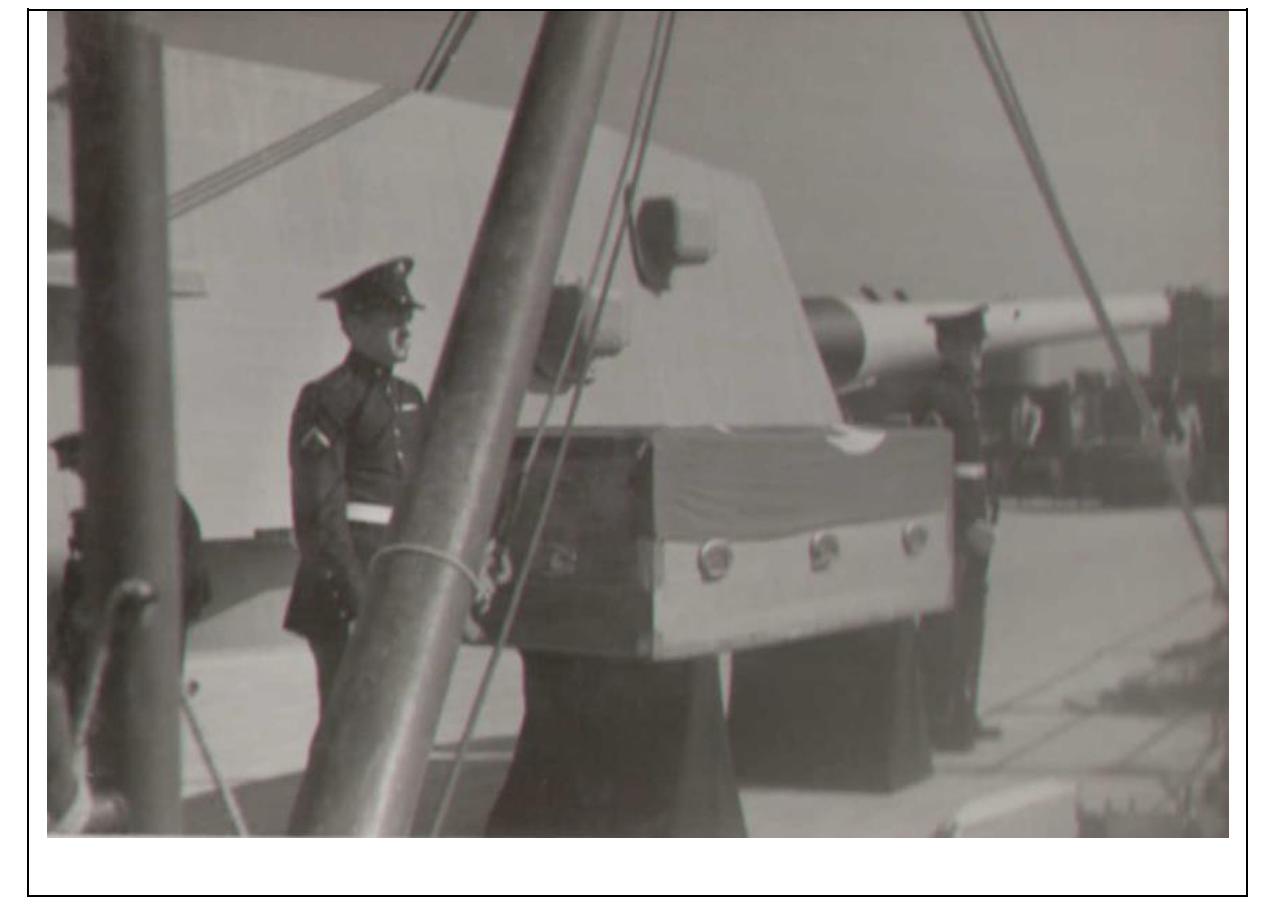

Ek 11: Missouri Zırhlısı İstanbul'a Ulaştığında Münir Ertegün'ün Naaşı Güvertede

Nakledilmeyi Beklerken. Donanma Komutanlığı Deniz Tarihi Arşiv Kısmı Fotoğraf Arşivi, 5 Nisan 1946.

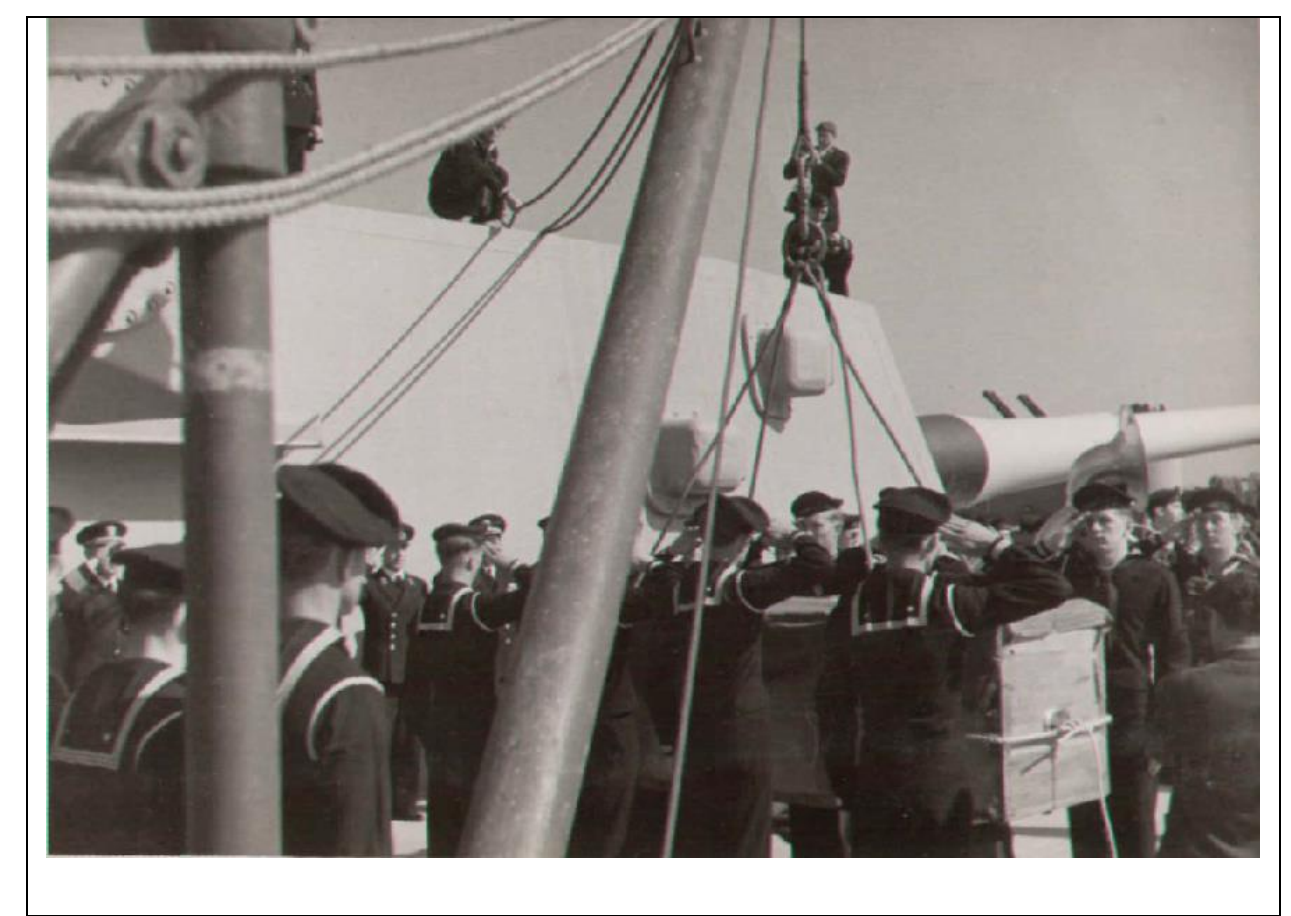

Issue 3

June

2020

Ek 12: Münir Ertegün'ün Naaşı Karaya Çıkartılacağı Motora Aktarılırken. Donanma Komutanlığı Deniz Tarihi Arşiv Kısmı Fotoğraf Arşivi, 5 Nisan 1946. 


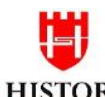

HISTORY

959

Volume 12

Issue 3

June

2020

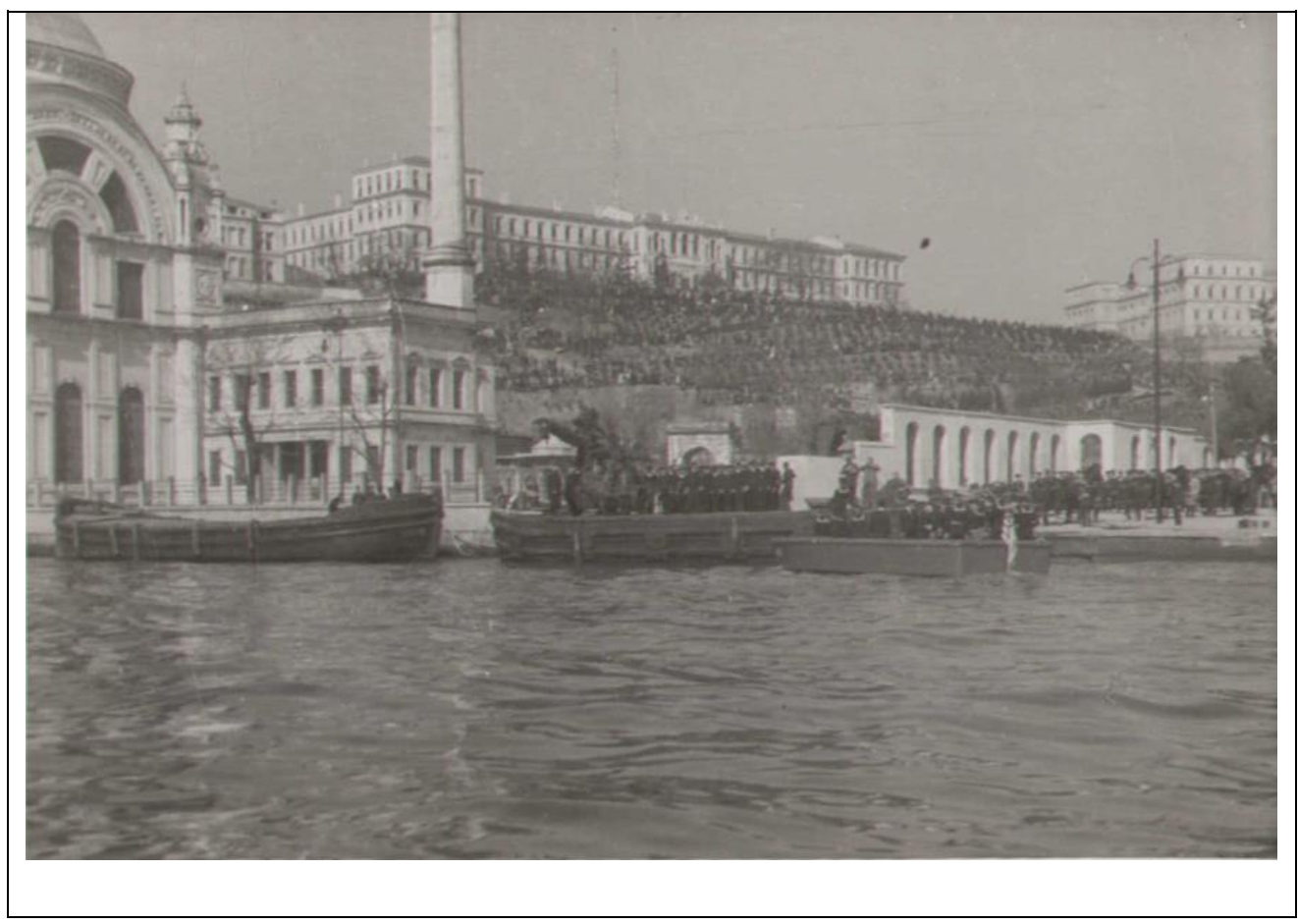

Ek 13: Münir Ertegün'ün Naaşı Motorla Dolmabahçe'ye Çıkarılırken. Donanma Komutanlığl Deniz Tarihi Arşiv Kısmı Fotoğraf Arşivi, 5 Nisan 1946.

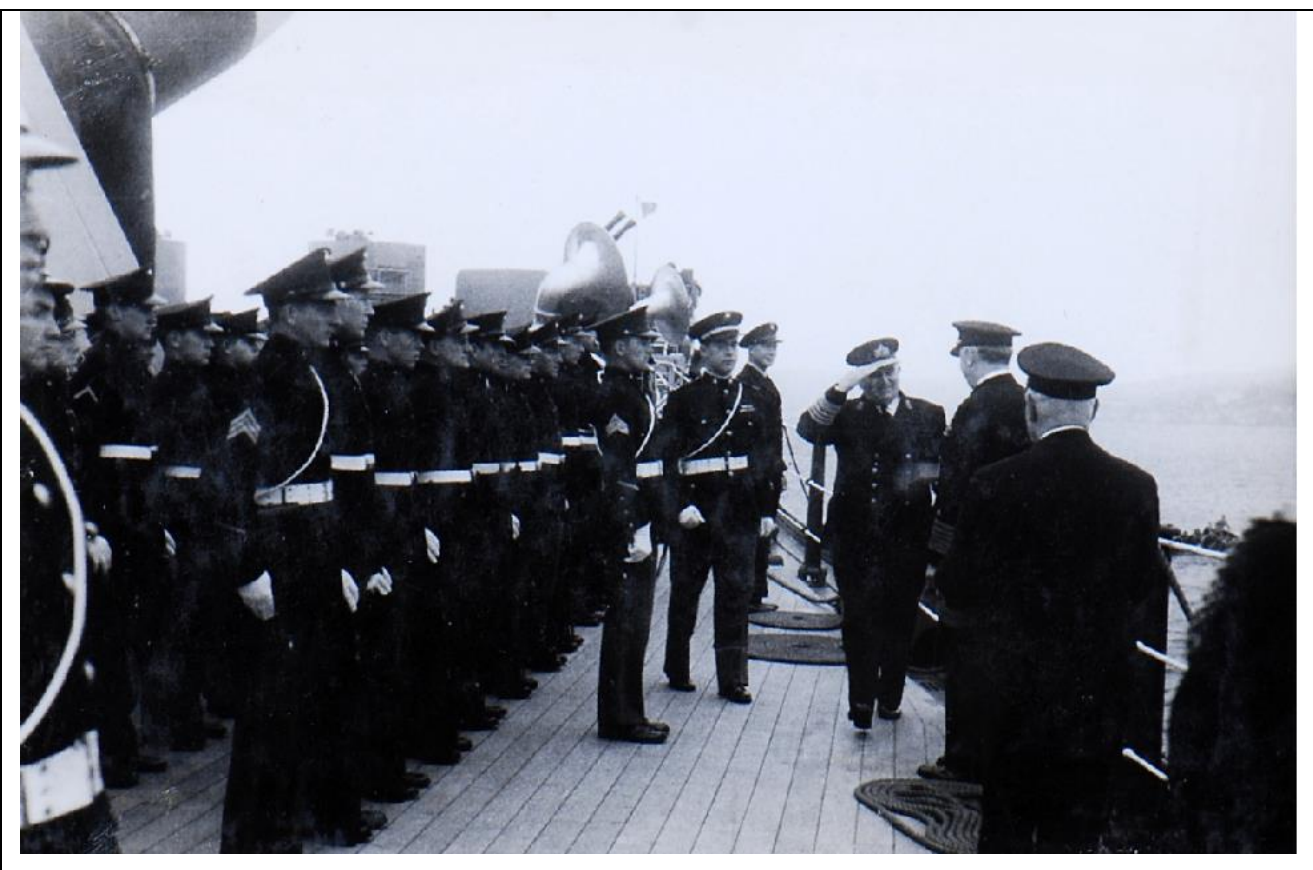

Ek 14: Donanma Komutanı Kormiral Mehmet Ali Ülgen, Missouri Zırhlısını Ziyaret Ederken. Donanma Komutanlı̆̆ı Deniz Tarihi Arşiv Kısmı Fotoğraf Arşivi, 5 Nisan 1946. 
Cumhuriyet Devri Diplomat Naaşlarının Nakillerinde Savaş Gemilerinin Kullanılması Örnekleri...

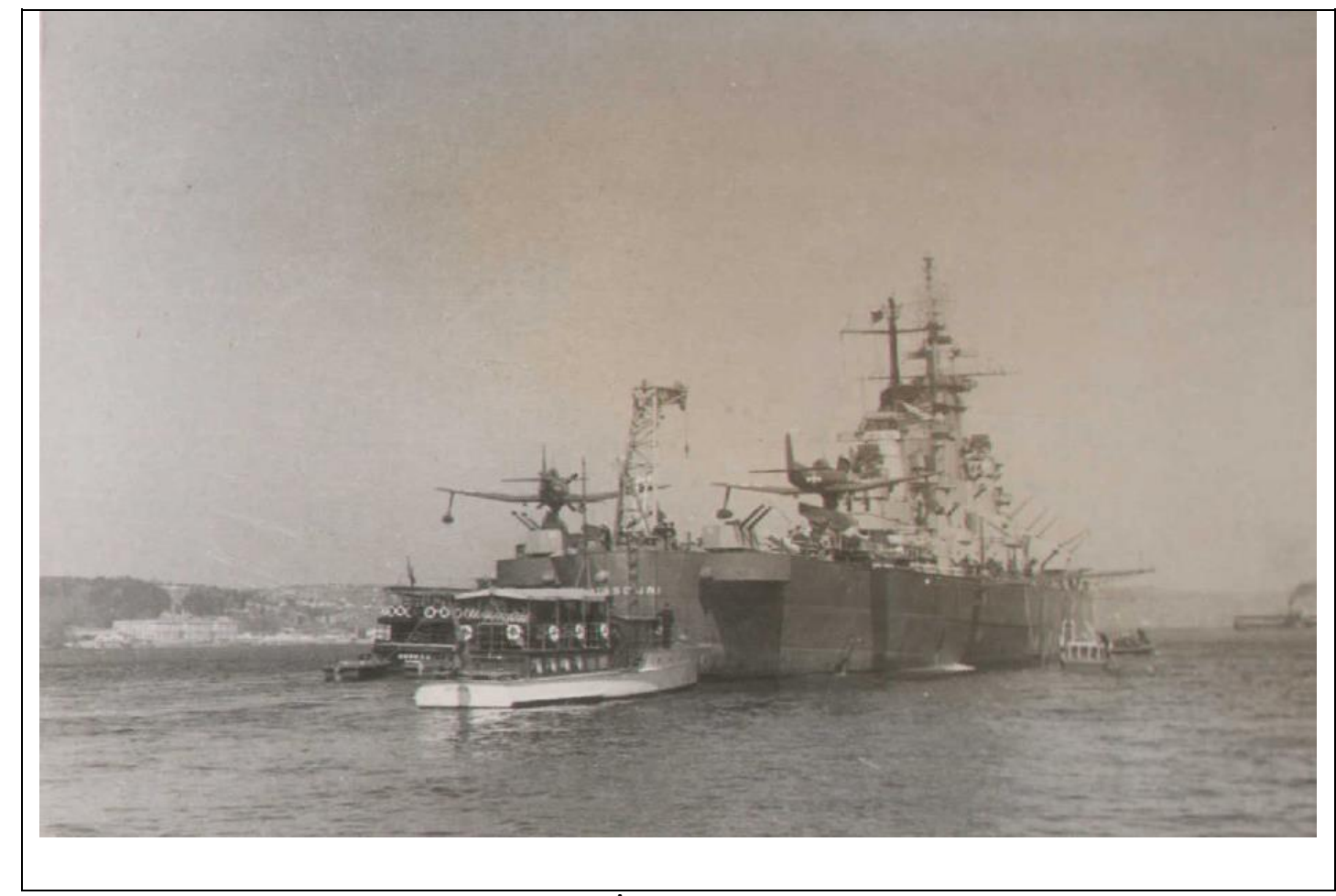

Ek 15: Missouri Zirhlısını Ziyaret Edecek İstanbulluları Getiren Vapur ve Motorlar. Donanma

Komutanlı̆̆ı Deniz Tarihi Arşiv Kısmı Fotoğraf Arşivi, Nisan 1946. 